\title{
The personalized medicine: today and tomorrow
}

Mohammad Reza Noori-Daloii ${ }^{1}$, Narges Zafari ${ }^{2}$

1 Professor, PhD of Medical Molecular Genetics, Department of Medical Genetics, School of Medicine, Tehran University of Medical Science, Tehran, Iran

${ }^{2}$ MSc Student of Medical Genetics, Department of Medical Genetics, School of Medicine, Tehran University of Medical Science, Tehran, Iran

Recent genetic findings and correlated developments in genomic techniques have led to the commercialization of novel diagnostic platforms for studying disease or evaluating therapeutic results in patients. This field is known as "personalized medicine," and uses the patient's genetic structure to tailor approaches for patient specific disease detection, treatment, or prevention. Personalized medicine is embedded in the belief that since individuals have unique features at the molecular, physiological, environmental exposure, and behavioral levels, they may need to have mediations provided to them for diseases they have that are tailored to these unique characteristics. Personalized diagnostic tests are used to identify patient-to-patient differences in gene or protein expression levels, which performance as indicators for drug treatments or disease prognosis. In order, medical experts be able to better answer questions such as: "who must be treated with which drug?" and "How should the treatment be ordered?" Clinical genetic testing began over 30 years ago with the accessibility of mutation detection. Since then, the field has intensely altered to include genome sequencing and genome-wide analyses using microarrays and nextgeneration sequencing. The identification of deoxyribonucleic acid (DNA) sequence variants related with common diseases stimulated the availability of testing for personal disease risk estimation, and created commercial opportunities for direct-to-consumer genetic testing companies that examine these variants. This genetic risks, are the key components of the personalized medicine, which aims to apply personal genomic and other relevant data into a patient's clinical valuation to more accurately guide medical management. Direct-to-consumer (DTC) DNA testing, by providing a wide range of personal genomic information directly to its consumers. These companies, illustrated by the well-established 23 andMe, usually carry out an analysis of single nucleotide polymorphisms (SNPs) using DNA extracted from a saliva sample. These genetic data are then assimilated and provided direct to the customer, with different interpretation.

Keywords: Personalized medicine, Pharmacogenomics, Precision.

Cited as: Noori-Daloii MR, Zafari N. The personalized medicine: Today and tomorrow. Medical Science Journal of Islamic Azad University, Tehran Medical Branch 2019; 29(1): 1-17.

Correspondence to: Mohammad Reza Noori-Daloii

Tel: +982188953005

E-mail: nooridaloii@sina.tums.ac.ir

ORCID ID: 0000-0002-9044-9842

Received: 15 Dec 2018; Accepted: 18 Feb 2019 
مجله علوم بزشكى دانشگاه آزاد اسلامى

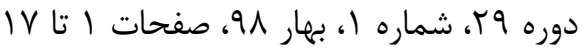

Review

Article

\section{امروز و فرداى :زشكى شخصى شده}

\section{محمدر ضا نورى دلوئى'، نر گس ظفرى}

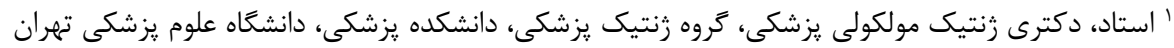

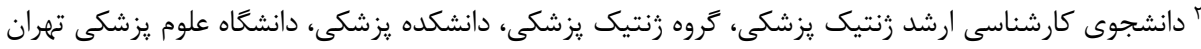

\section{جكيده}

اكتشافات زنتيكى اخير و تحولات مربوط به آن در تكنيكهاى ثنوم منجر به تجارى سازى سيستهم هاى جديد تشخيصى براى مطالعه بيمارى

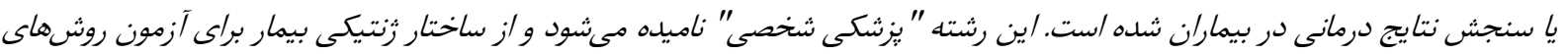

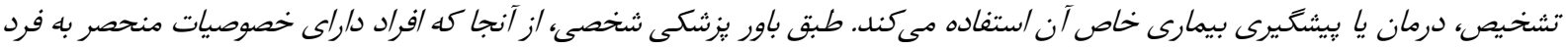

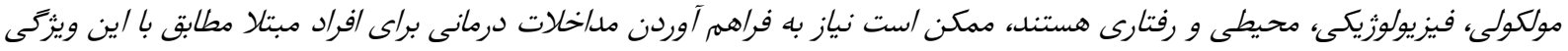

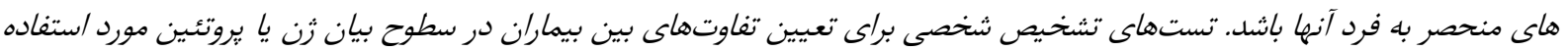

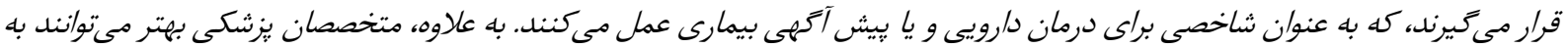

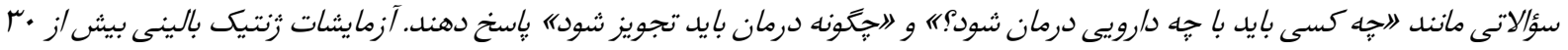

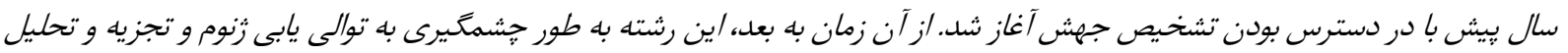

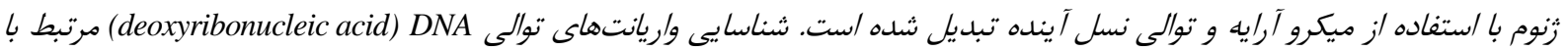

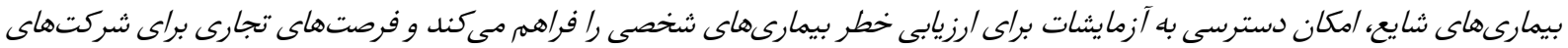

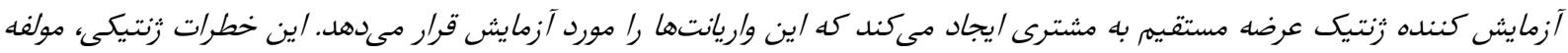

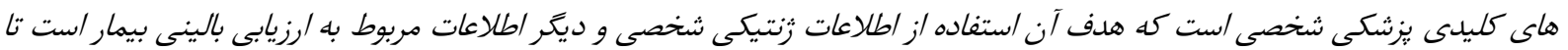

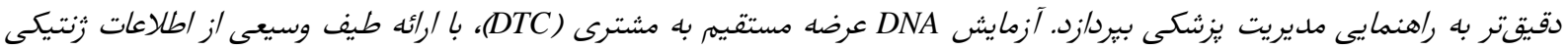

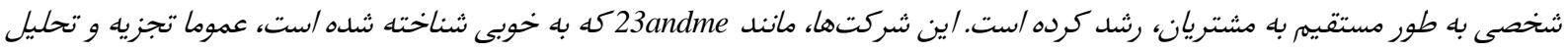

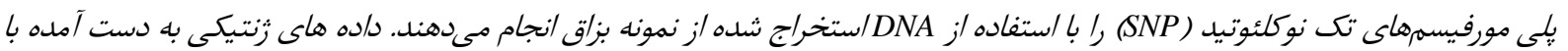

$$
\text { تفسيرهاى متفاوت، به طور مستقيم به مشترى /رائه مى مشود. }
$$

وازكان كليدى: يزشكى شخصى، فارماكوزنوميك، درمان هدفمند.

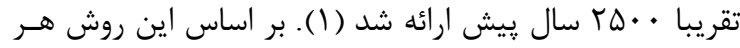

مقدمه

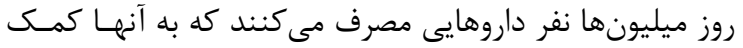

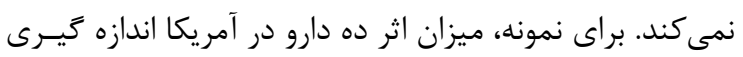

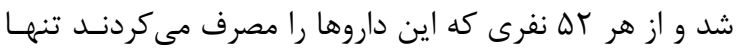

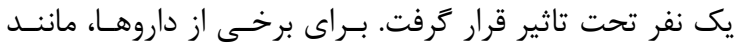

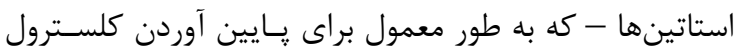

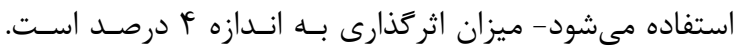
الكَوى كنونى مراقبت هاى سلامتى مدرن بر تشـخص بيمـارى

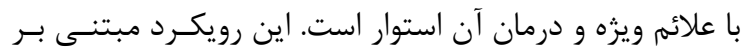

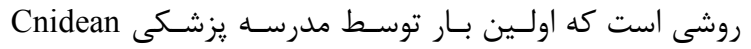

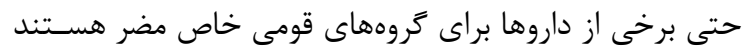

آدرس نويسنده مسئول: تهران، دانشكاه علوم يزشكى تهران ، دانشكده يزشكى، كروه زُنتيك يزشكى، دكتر

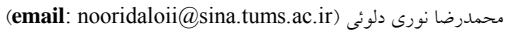
ORCID ID: 0000-0002-9044-9842 تاريخ دريافت مقاله: 9V/4/TY تاريخ بذيرش مقاله: تاريخ درياف مقال: 


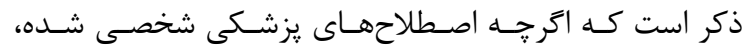

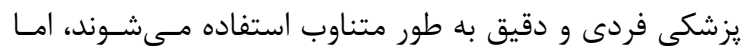

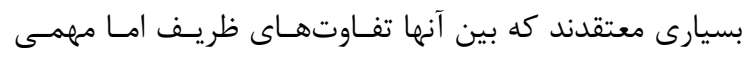

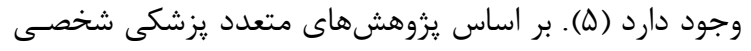

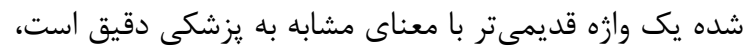

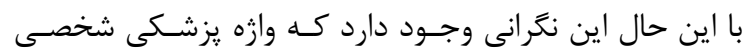

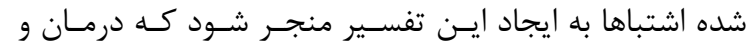

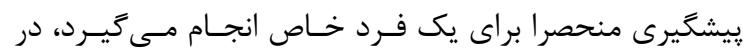

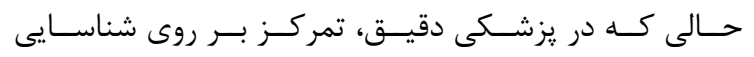
رويكردهايى است كه بتواند بر اساس زنتيك، محسيط و شئيون

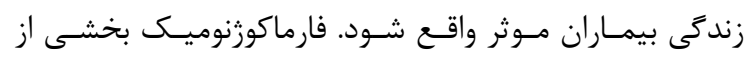

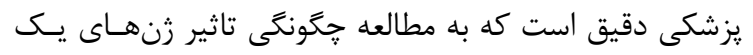

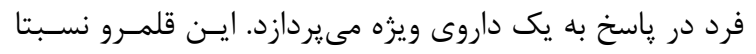

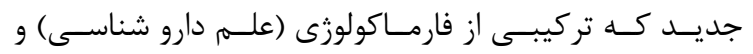

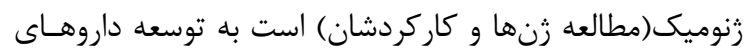

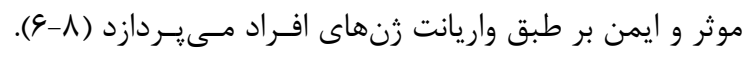

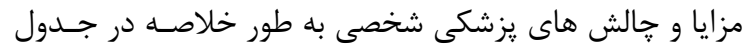

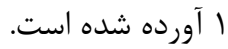

\section{كذشته و حال يزشكى شخصى شده}

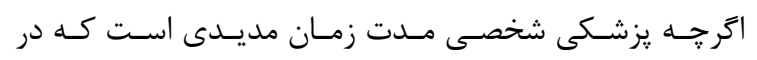

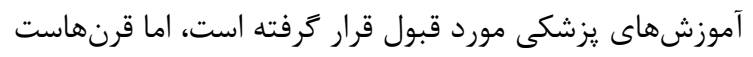

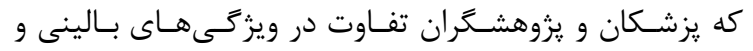

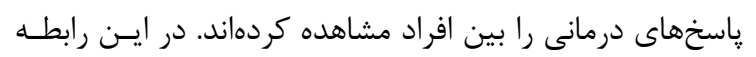
نمونههاى متعدد تاريخى از جمله موارد زير وجود دارند

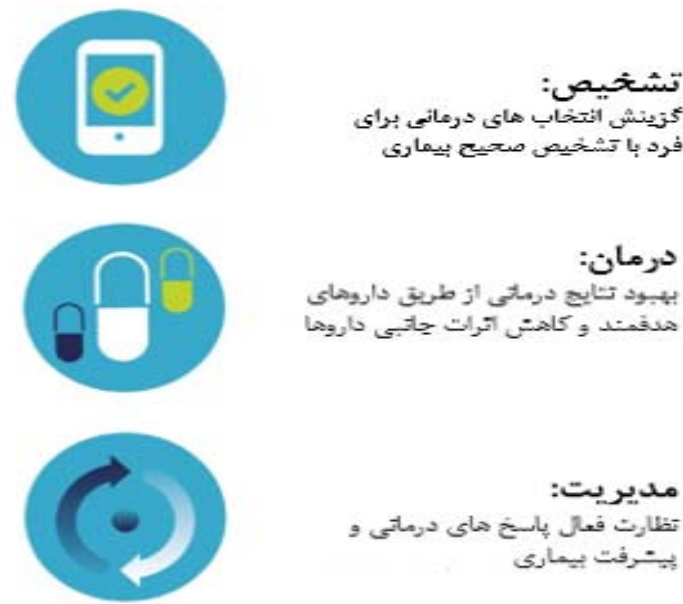

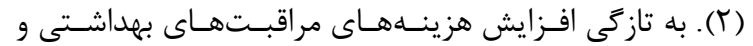

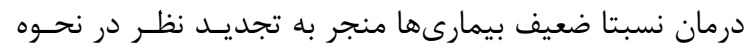
انجام مراقبت هاى يزشكى و ظهور يزشكى شخصى شده شده است

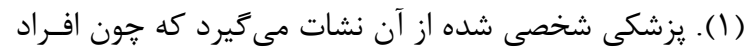

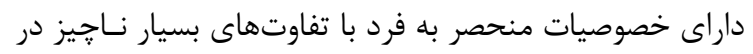

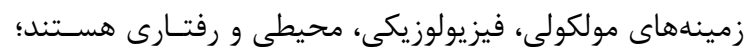

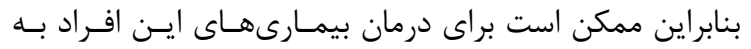

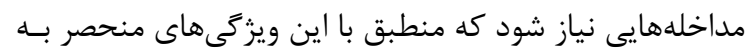

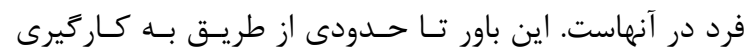

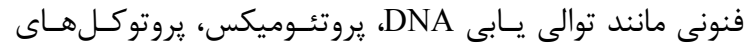

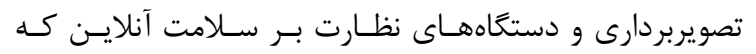

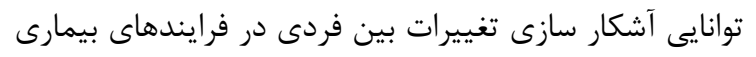

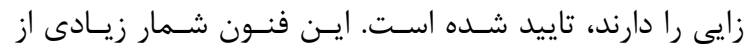

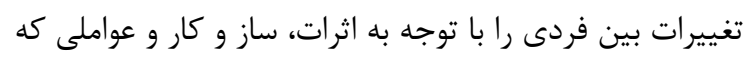

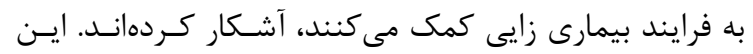

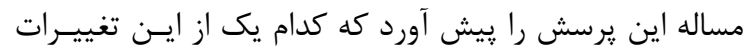

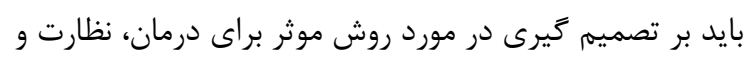

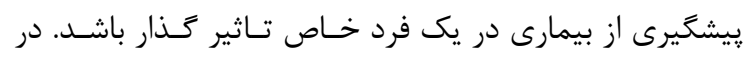

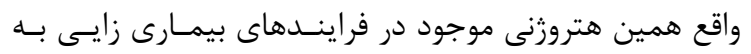

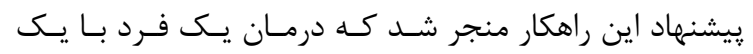

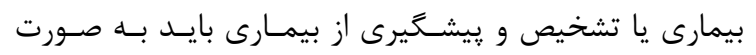

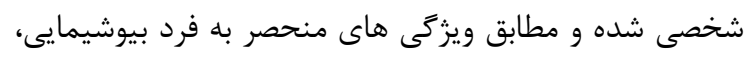

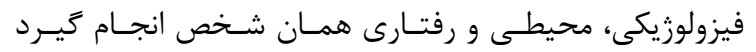

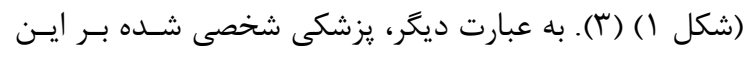

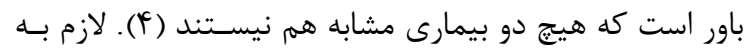

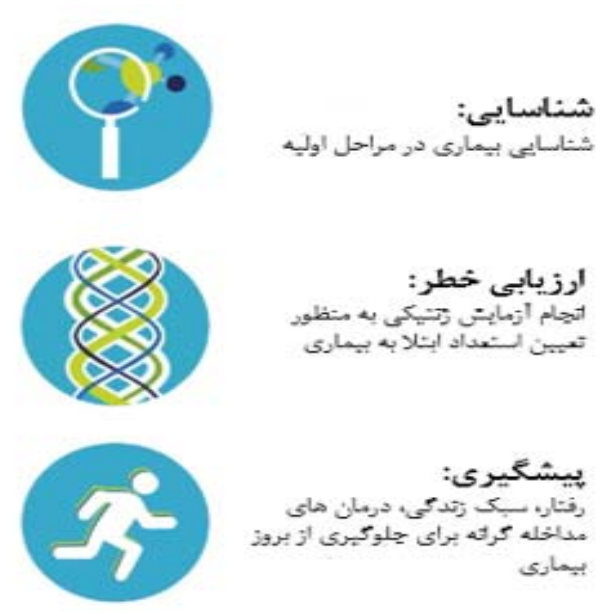

شكل ا. نظرى كذرا بر بزشكى شخصى شده 


\begin{tabular}{|c|c|}
\hline جالش ها & مزايا \\
\hline هزينه بالاى آزمونها & صرفه جويى در هزينههاى مراقبت از سلامت \\
\hline فقدان بيوماركر ٍِيشَويى كننده معتبر براى بسيارى از بيمارىها & ريش گَيى خطر ابتلا به بيمارى \\
\hline فقدان نسبى درمانهاى جايخزين مشخص (براساس تفاوتهاى رنتيكى) & 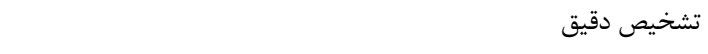 \\
\hline فقدان علم و تخصص كافى بسيارى از يزشكان در زمينه زنتيك، & شناسايى بيمارى در مراحل اوليه براى به تاخير انداختن پيشرفت بيمارى \\
\hline تخمين خطر و مشاوره زنتيك (•) & 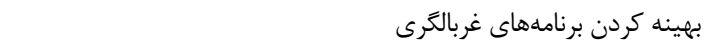 \\
\hline دشوارى نسبى تفسير داده هاى زنومى با افزايش سريع ظرفيت توالى يابى & فراهم آوردن اطلاعات ييش آكمى صحيح \\
\hline هتروزنى بين بيماران، هترورنى درون تومور و مقاومت اكتسابى بيماران به & بهينه سازى مداخلات درمانى \\
\hline
\end{tabular}

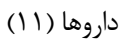

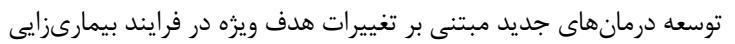

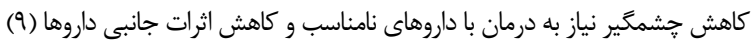

ادغــام زنتيــك، بيوشـيمى و فارمــاكولوزى تحست عنـوان

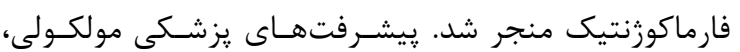
زمينه تازهاى از فارماكوزنوميك را ايجاد كرده اسـت كـه بــه

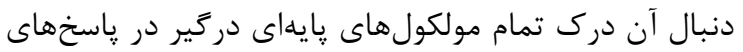

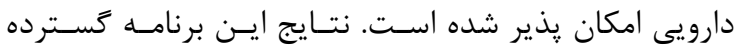
يزوهشى اكنون به عنوان يزشكى شخصى شناخته مىشـود.

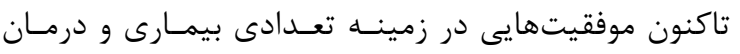

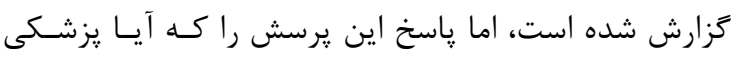

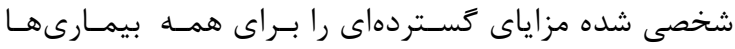

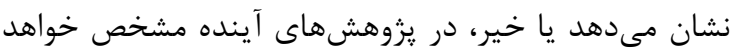

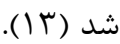

از سويى ديكر، يروزه زنوم انسان تنهــا بـهـ اولـين تـوالى يـابى

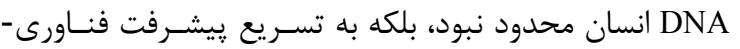

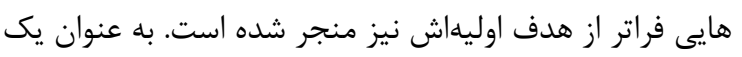
نتيجه از جنين فناورىهايى مىتوان به انواع متفاوت دادههاى

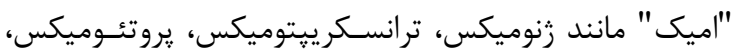

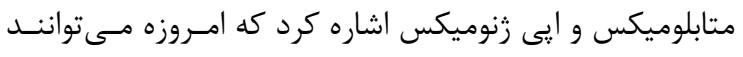

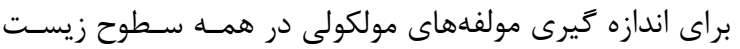

شناختى مرتبط توليد شوند (If).

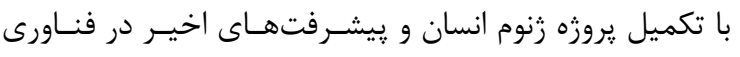

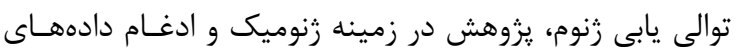

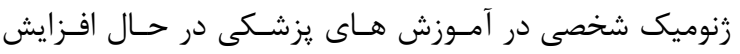
است. اخرجه درى نقش زنتيك در بيمارى هــاى انسـان هنـوز

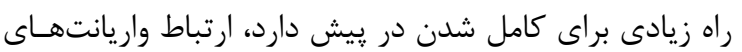

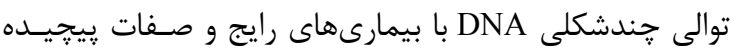
(Genome-Wide Association Study) GWAS بـه وسـيله شناخته شده است (I (I).
AL Fox -

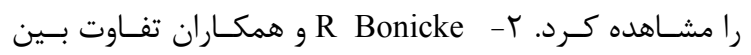
بيماران درعدم تغيير ايزونيازيد طـى دفـع در ادرار را توصـيف

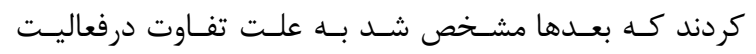

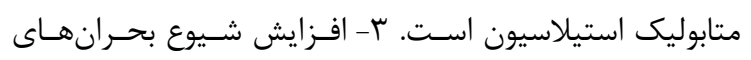

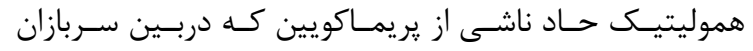

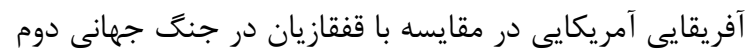

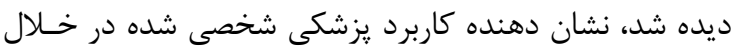
سده اخير است. با وجود اين نمونهها، و نمونههاى ديگرى كـهـ

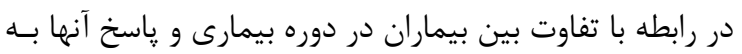

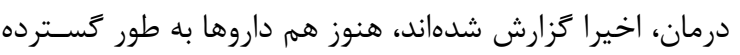

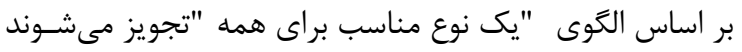
به نحوى كه بيماران مبتلا به يك بيمارى خاص تحست درمـان

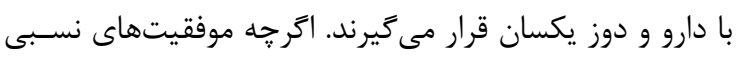

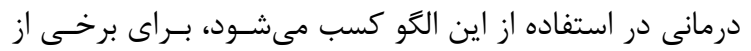

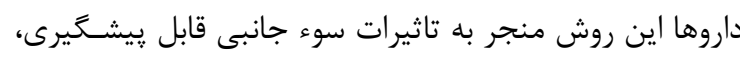

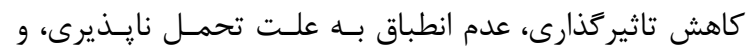

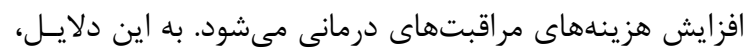

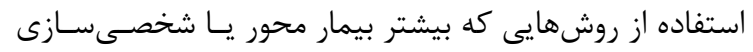

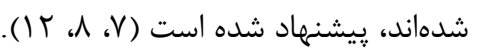
در خلال شش دهه كذشته، شـواهد زيـادى مبنـى بـر اينكـهـ بخش قابل توجهى از تفاوت در ياسخ به داروها به زنتيك فرد،

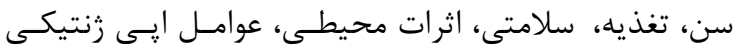

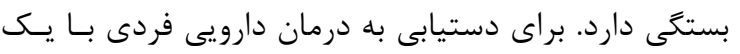

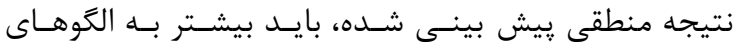

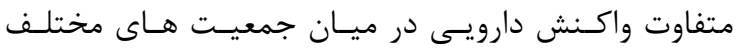

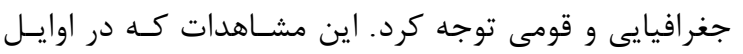
دهه • لهو آغاز شد، به تولد يك رشته روجه علمى جديد ناشـى از 


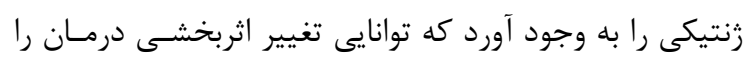

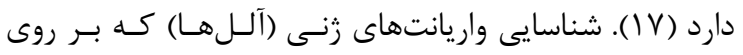

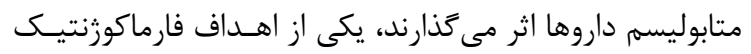

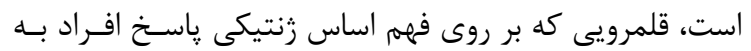

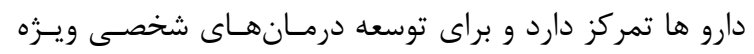

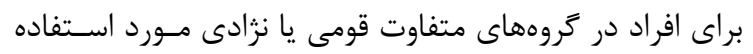

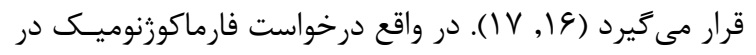

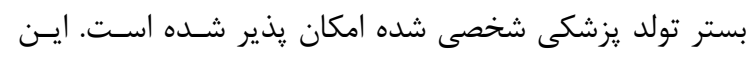

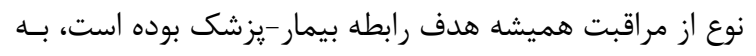

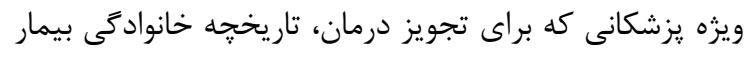

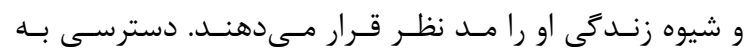

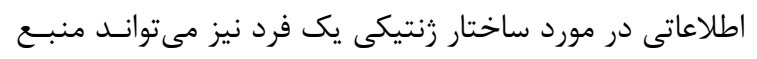

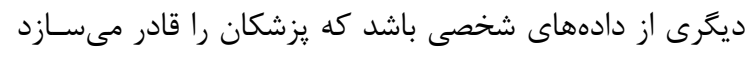

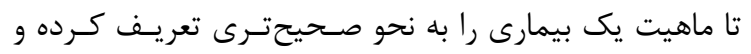

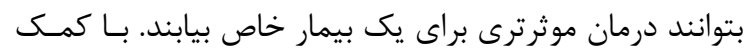

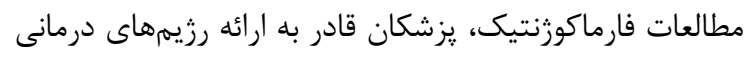

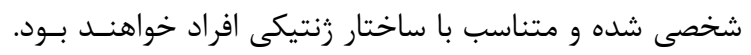

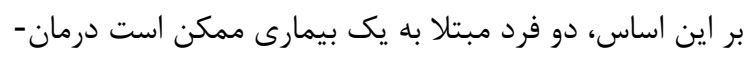

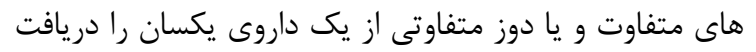

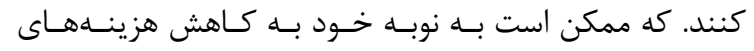

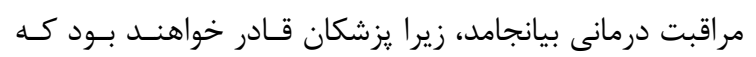

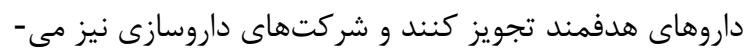

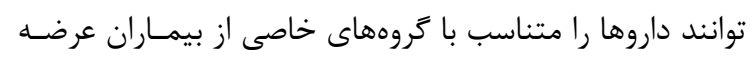

كنند (19).

كدئين يكى از داروهايى است كه متابوليسم آن تا حسد زيــادى

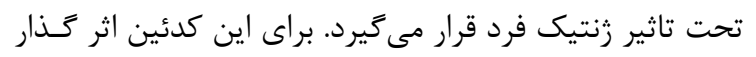

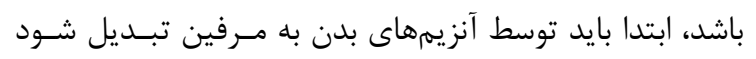

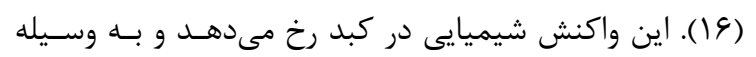

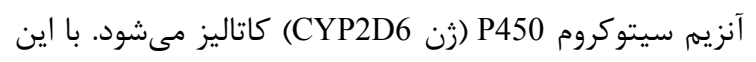

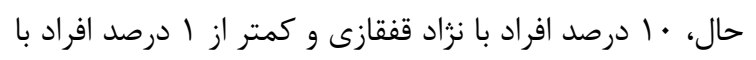

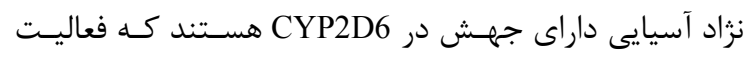

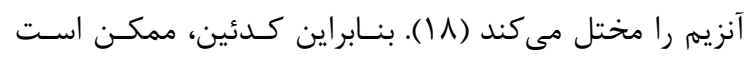

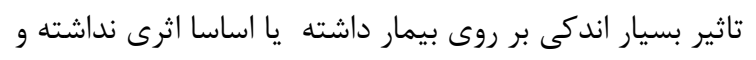

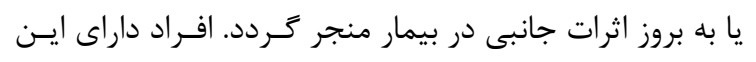

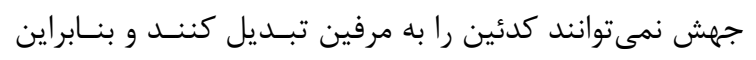

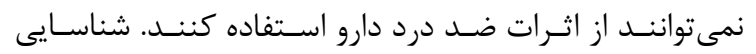

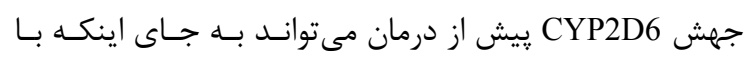

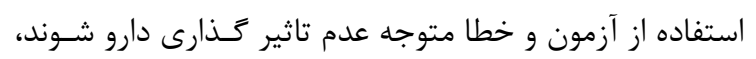

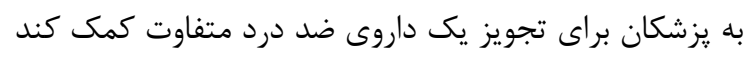

با توجه به كاربرد يزشكى، اين فناورىها موجب ايجـاد انكَيزه

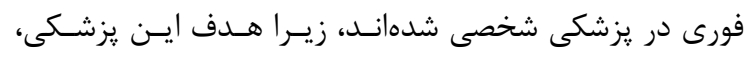

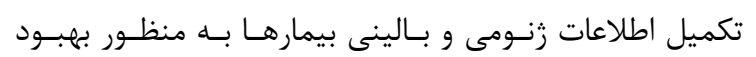

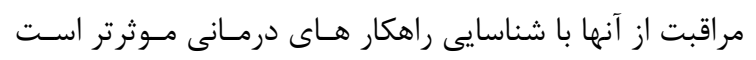

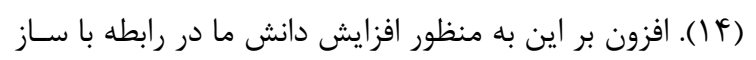

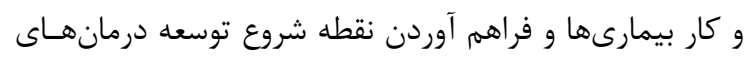

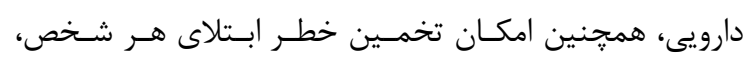

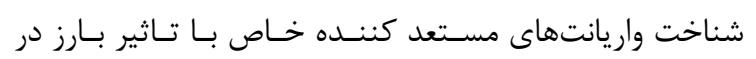

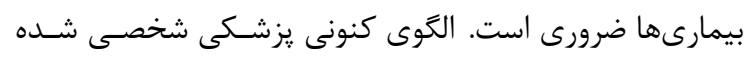

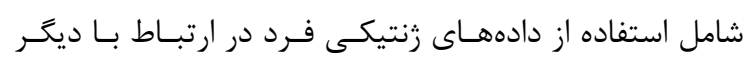

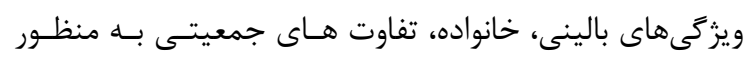

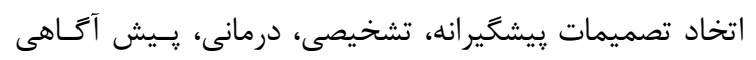

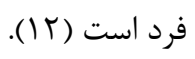

\section{يزشكى شخصى شده و تنوع زنتيكى}

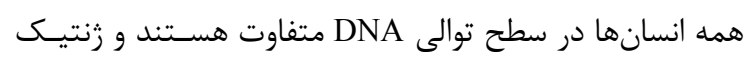

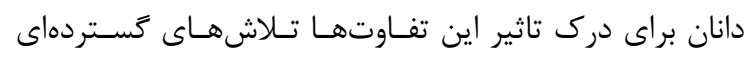

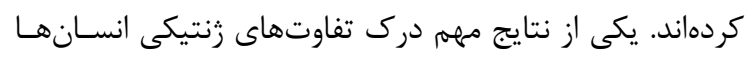

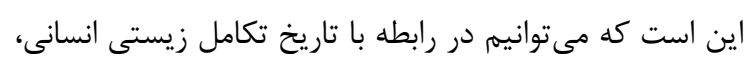

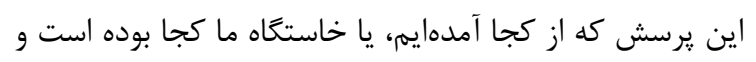

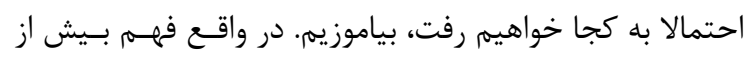

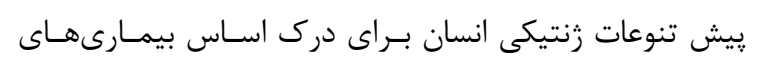

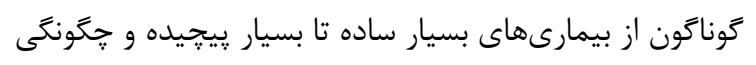

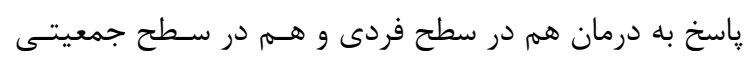

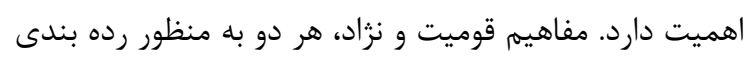

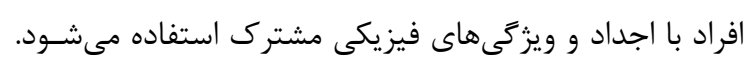

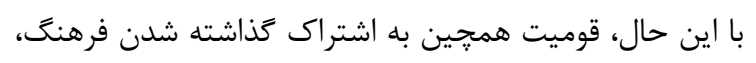

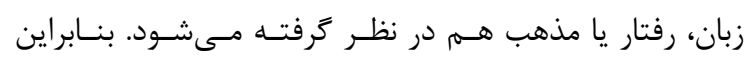

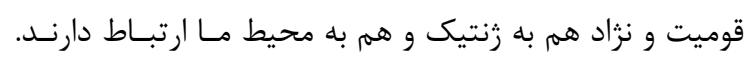

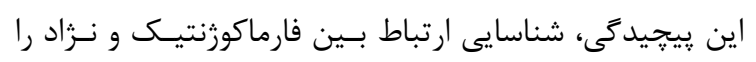

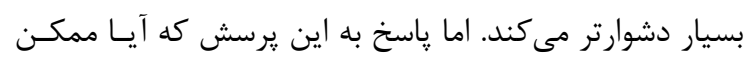

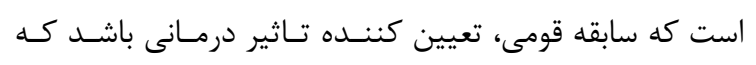

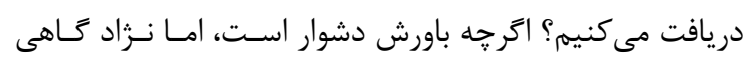

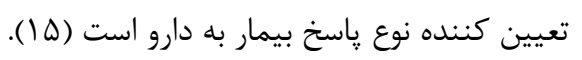

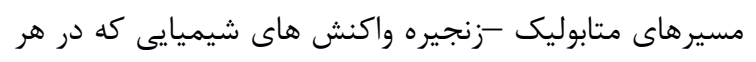

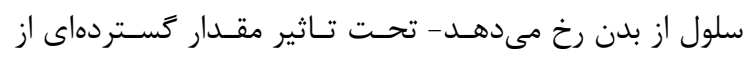

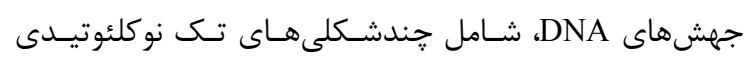

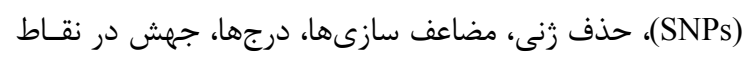

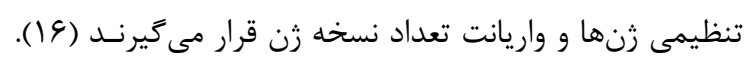

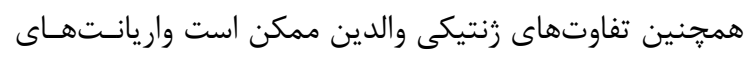


جامع واريانتهاى زنتيكى انسان است. يزوهشـگران در يـروزه هزار زنوم در يافتند كه سو درصد از واريانتهاى جديد (كه تـا

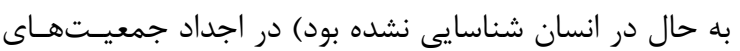
آفريقايى يافت مسىشـود در حـالى كـهـ تنهـا سبا درصـد ايسن

واريانتها در اجداد ارويايى ديده شدهاند (ه ().

در همان مطالعه، جند صد هــزار SNP بـا فراوانـىهـاى آللىى بسيار متفاوت در جمعيتهاى جغرافيايى مجزا يافت شدند. در

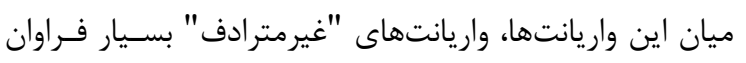
بود، كه به تغييرات مهلم در توالى DNA منجر مى آىود و دريى

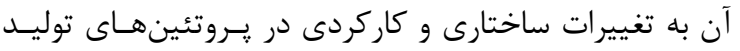
شده توسط اين زن ها مى انجامد. اين مشاهدات نشان مى ندهند

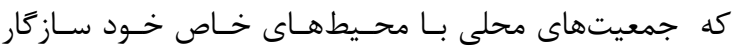
شدهاند كه علت اين امـر تغييـرات زنتيكـى اسـت كــه اجـازه

مىدهد اين اتفاق به وسيله تكامل زيستى تحقق يابد (ه (I). ب) دلايل اختصاصى بودن شديد جمعيتى جهشهـــ

مندلى (آنجا

از آنجا كه گَرَّل مندل، نخستين دانشمندى بود كـهـ بـر روى اساس قوانين وراثت كار مىكرد، به بيمارىهايى كه درون يك آنى خانواده به طور مشخص از قوانين وراثت توصيف شده توسط او ييروى مى كنند، بيمارىهاى مندلى كفته مىشوند. معمولا اين جهشها تاثير به سزايى در خطر ابتلا بـه بيمـارى (و كـاركرد

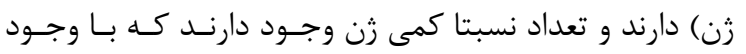
جهش تنها به ايجاد بيمارى با قابليت زنده ماندن موجود منجر

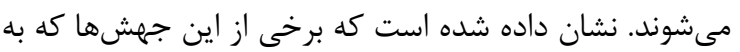

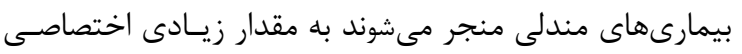

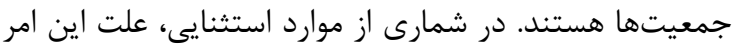
نتيجه انتخاب طبيعى مثبت بـرخلاف انتخـاب طبيعسى منفـى

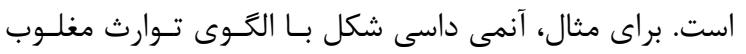
آتوزومى (كه به علت معيوب بودن دو نسخه يى زن م زلــوبين، از جمله توليد يروتئين با كاركرد كاهش يافته ايجاد مىشـود)،

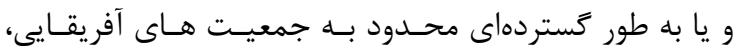
مديترانه اى و آسياى جنوبى است. در آفريقايى -آمريكـايىهــا،

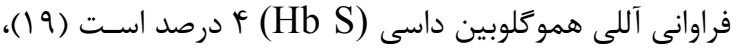

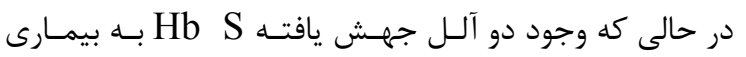

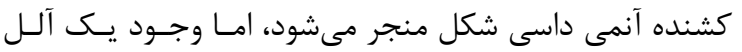

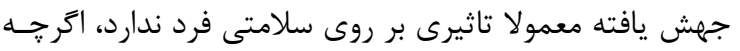
به مقاومت فرد نسبت به عفونت مالاريا مى انجامد. بــه همـين دليل اين آلل در مناطقى مانند آفريقا، مديترانه و آسيا جنوبى مله

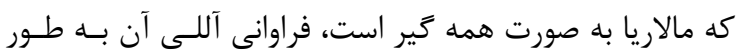

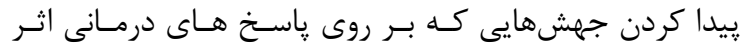

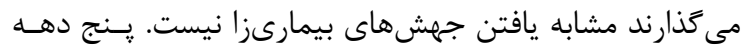

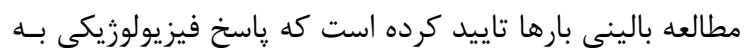
مواد شيميايى خاص مىتواند به ارث رسيده شود. در واقـع، از

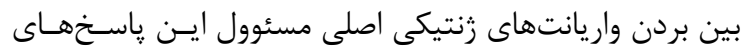

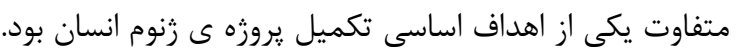

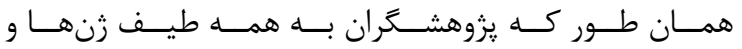
لوكوس(جايعاه)هاى زنتيكى زير نظر مسى گيرنـد در مسىيابنـد

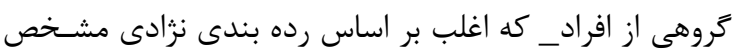

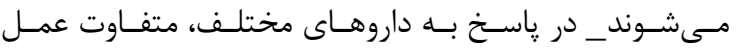

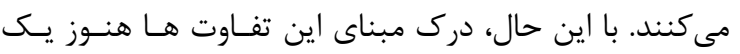
جالش محسوب مىشود (19).

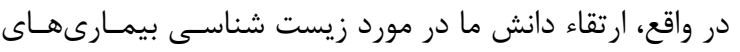

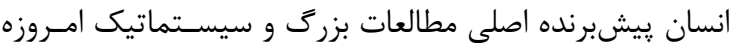

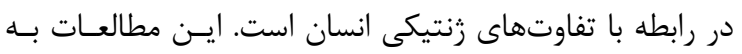
فراهم آوردن زمينه يزوهش در رابطه با جمعيتها و بيمـارىهاى اختصاصى آن ها منجر شده است و براى كاهش تفــاوت-

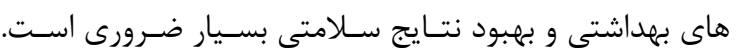

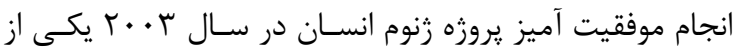

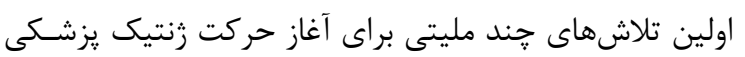

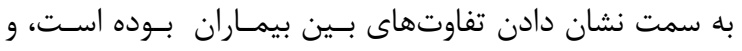

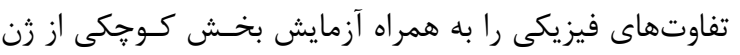

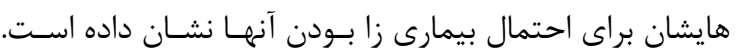

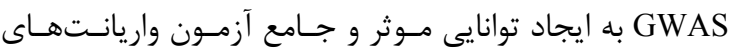
زنتيكى رايج در جمعيت و شناسايى رايجترين آنها در بيمـاران

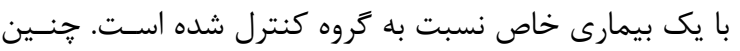

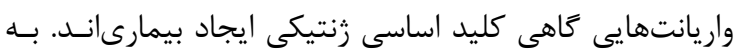

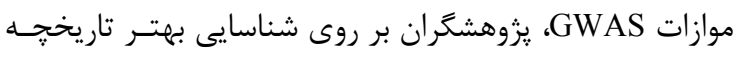

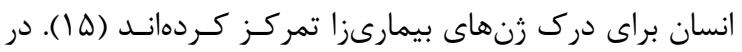
رابطه با يزشكى شخصى شده و تنوع زنتيكى مسى تــوان مـوارد زير را بحث كرد:

الف) الكَوى واريانتهاى جغرافيايى مربوط بــه تغييـرات

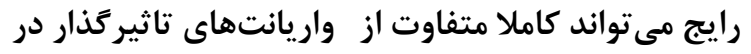

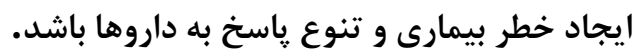

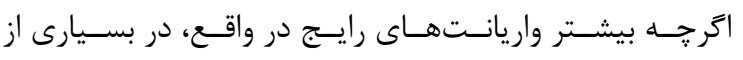

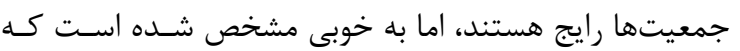
واريانتهاى نادر زن مى توانند الكَى كاملا متفاوتى را در ميان

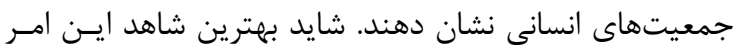

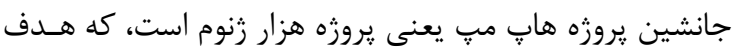

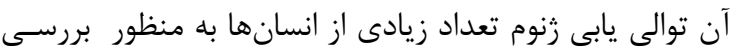


خود نيز كمك كرده است تا آللهاى تاى ساكس را در جامعـهـ با فراوانى نسبتا بالا حفظ كنند. امروزه فراوانى حاملين بيمارى

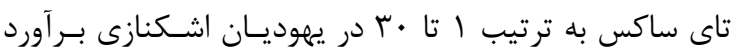

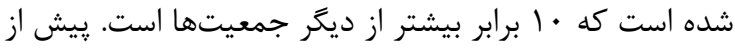

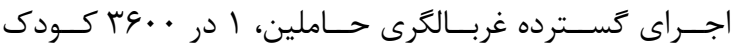

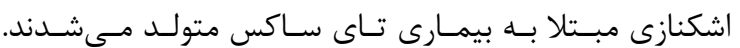
غربالكرى به كاهش •9 درصد ابتلا به تاى ساكس در يهوديان

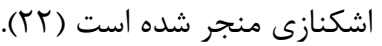
در ساير مواردى كه يك بيمارى زنتيكى خاص خداص در يك جمعيت

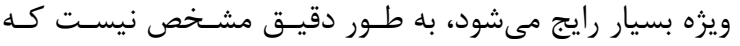

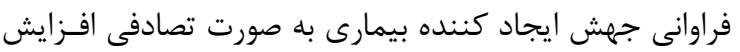
يُيدا كرده است يا اين كه ناشى از ازدواج انتخابى ميان حاملين يك جمعيت، برترى هتروزيخوسيتى و يا تركيبى از مـوارد بـالا

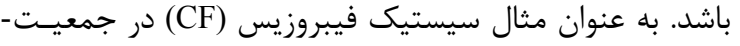

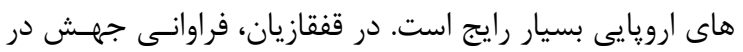

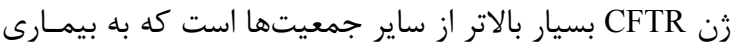

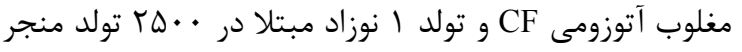

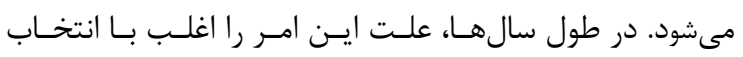
داروينيسم توضيح دادهاند، به اين ترتيـب كـه شـايد حـاملين جهش CFTR نسبت به بيمارىهاى روده اى از دست دهنــده

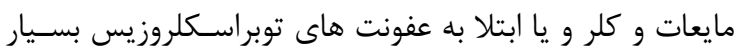

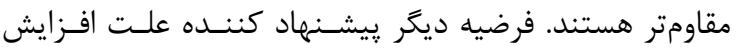
حاملين در ارويا اين است كه با افزايش كاوهاى شيرده در اين

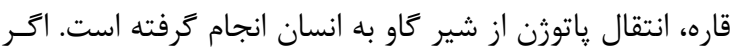

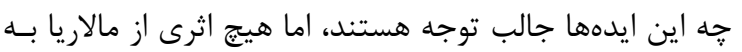

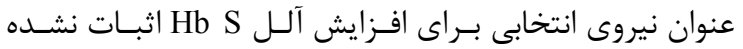

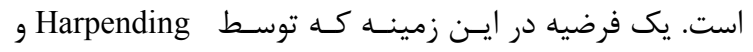
مطرح شده است اين است كسه جهـشهـاى ايجـاد كننده تاى ساكس و ديكر بيمارىهاى ذخيره ليزوزومى كه بـاسـا

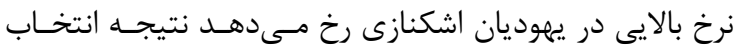

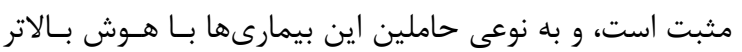

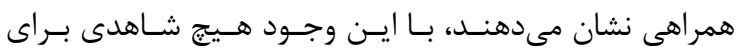

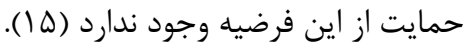

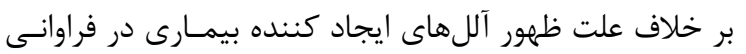

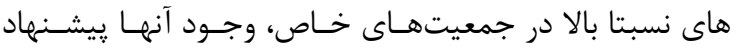
كننده اين احتمال است كه واريانـتهــاى نـادر هـم در ايجــاد

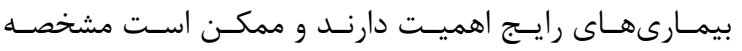

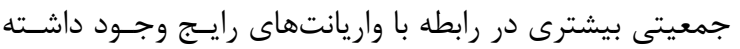

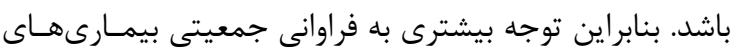

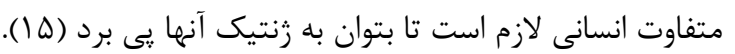

بارزى در ميان جمعيت هايى با منشاهاى ذكر شده بالاست. به

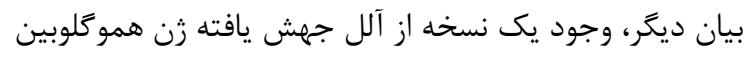

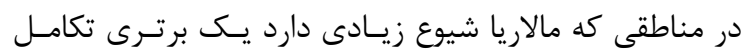

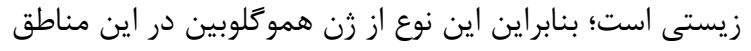

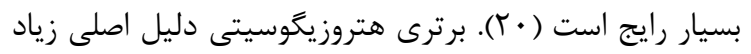

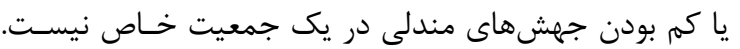
به طور اساسى، جهشهايى كه تاثير بسيار عمده بر روى خطر برد

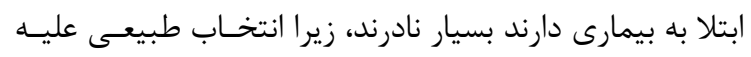

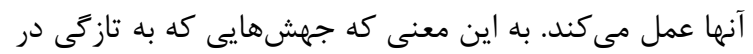

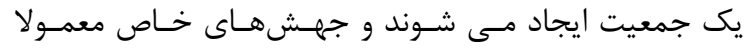

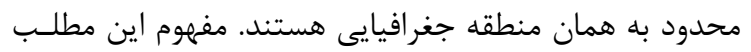

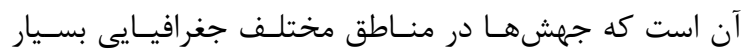
متفاوتاند، اما بار كلى بيمارى كه توسط آنها ايجاد مىشود به به ديه

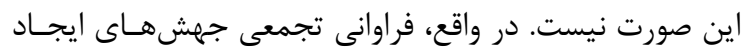

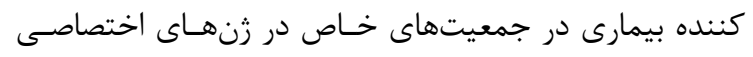

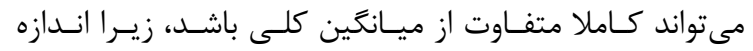

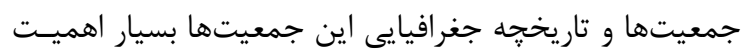

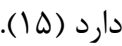
جنان جه جمعيت يهوديان اشكنازى را در نظر بخيريم، از نظـر

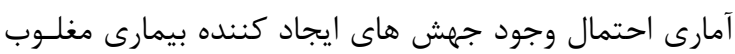

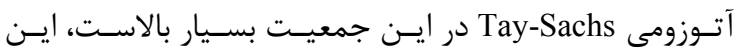
بيمارى به مرك كودكان در سنين بايين منجر مى شـود زيــرا

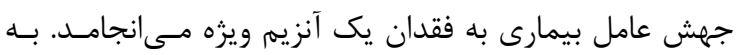

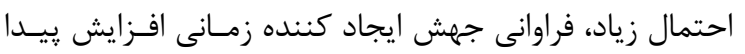

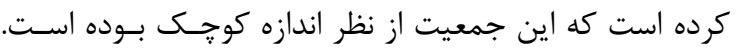

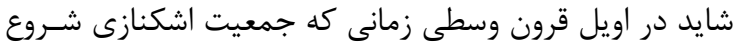

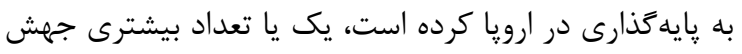
تاى ساكس به صورت تصادفى ايجاد شده و به علـت جمعيـت آنست

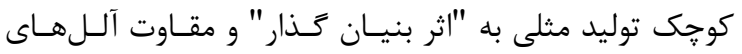

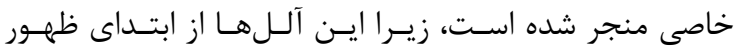

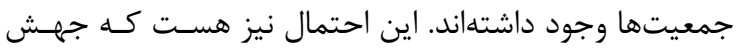

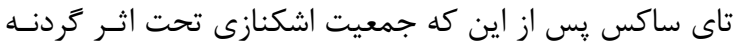

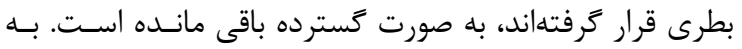

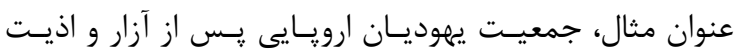

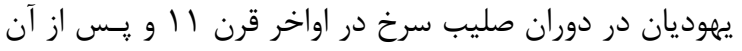

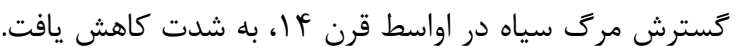

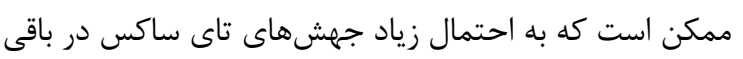
ماندكان اشكنازى يس از اين حوادث وجود داشته باشد و ايسن

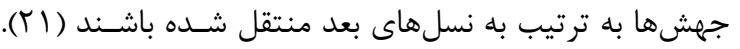

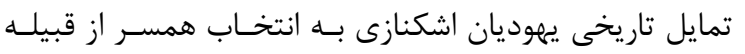


موثر در ياسخ به دارو نقش دارند. اين مساله به كاربرد آزمـون

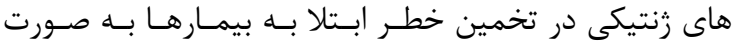

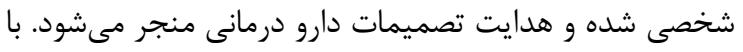

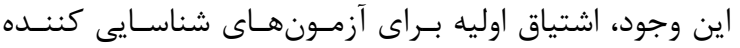

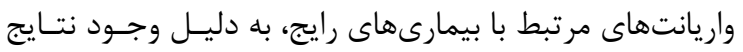

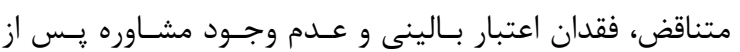
افشاى نتايج آزمونهاى زنتيكى، تخمين خطر ابتلا به بيمـارى

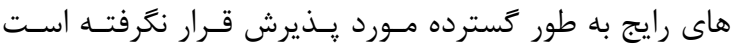

به طور كلى، آزمونهـاى زنتيكسى بـر روى بـ نـوع از تغييـرات

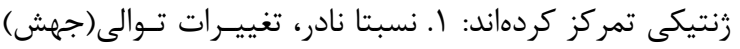

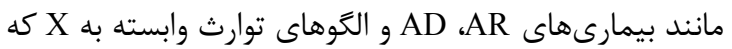

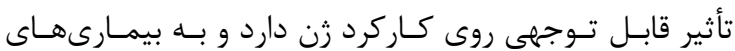

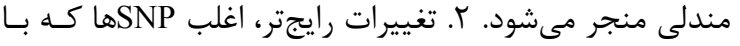

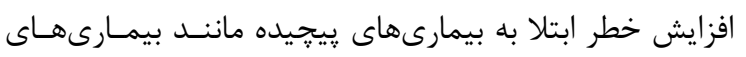

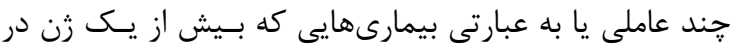

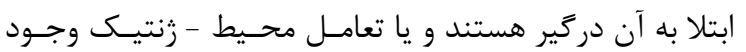

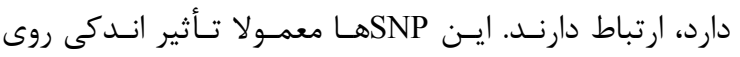

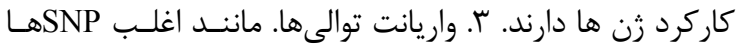

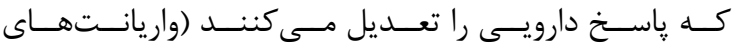

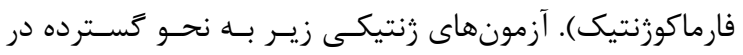

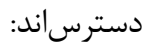

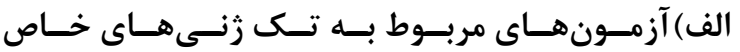

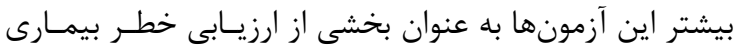
هاى ارثى يا براى تشخيص بيمارىها، به كار كرفته مىشـوند.

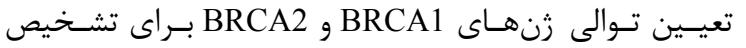

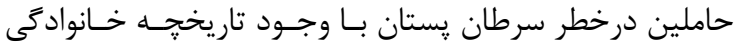

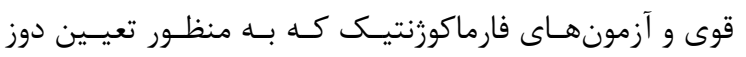

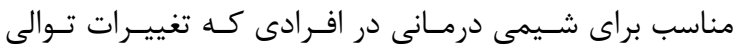

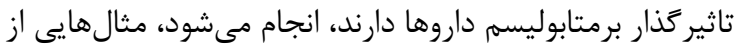

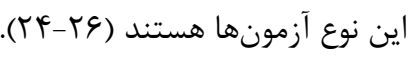

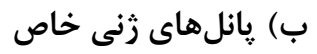

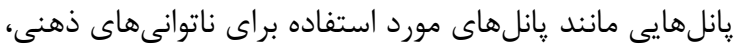

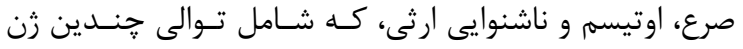

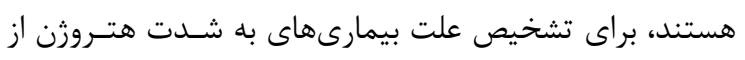

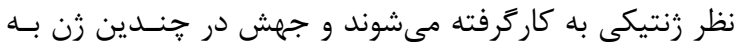
ايجاد همان فنوتيب مي انجامد.

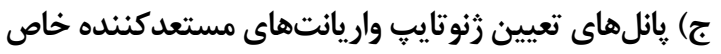

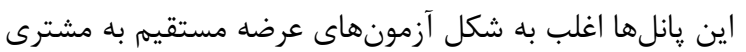

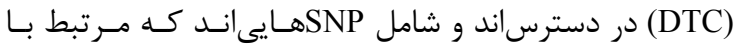

ج) واريانتهاى رايج تاثير كذار در خطر ابتلا به بيمـارى و تنوع ياسخ به داروها

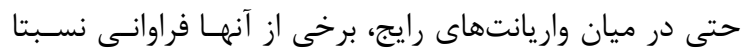

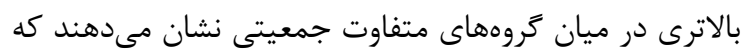

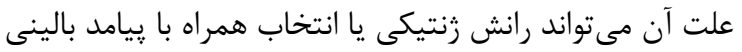

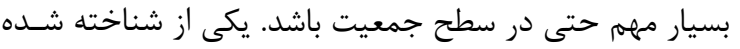

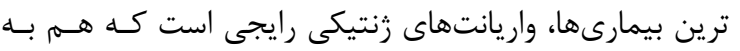
حذف خود به خودى عوامل عفونتزاى ويـروس هياتيـت C

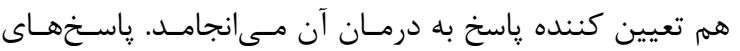

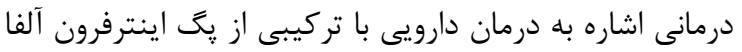

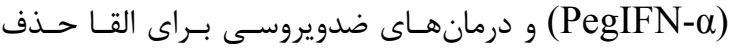

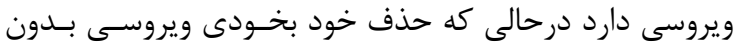

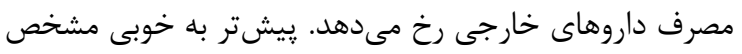

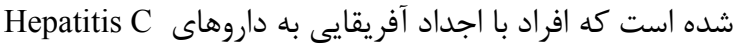
نسبت به افرادى كه اجداد قفقازى يـا آسـيايى دارنـد،

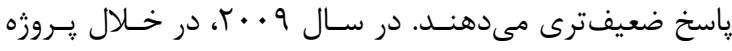

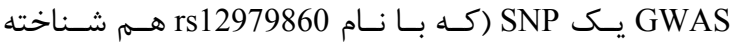
مىشود) در جايكاه IL28B شناسايى شد كه با پاسخ بيمـاران

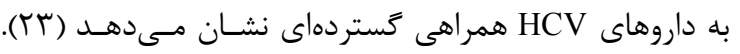
فراوانى آللى اين جند شكلىهاى IL28B در ميـان كَروههـاى نزادى مختلف، متفاوت است و همين امر توضيح دهنده تفاوت در نرخ موفقيت درمان در بين اين جمعيتهاست. IL28B كد

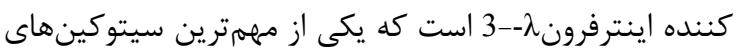

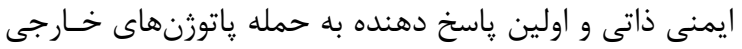

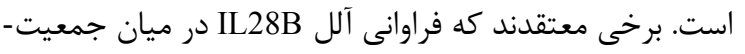

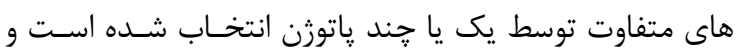

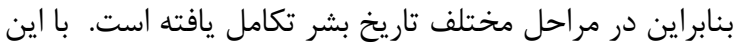

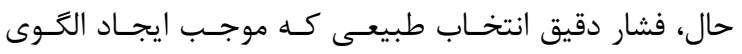
متمايز فراوانى آلل مىشود، مشخص نيست. به طوراب طور كلى كشف קند شكلىهاى IL28B نشان مى دهد كه توزيع فراوانى آلـلـ-

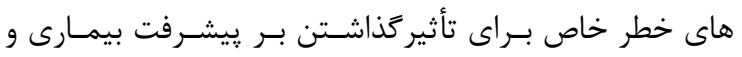
واكنشهاى دارويى كافى است (هاى (1).

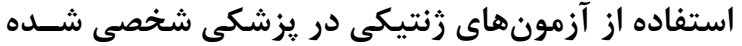
و كاربرد آن آن آن آن آن

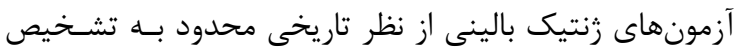

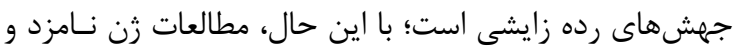

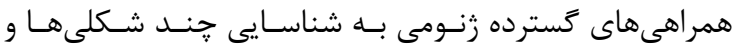

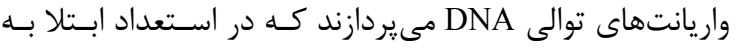
بيمارىهاى رايج، ساير صفات يِيجيده و شمارى از فنوتيبٍاى 


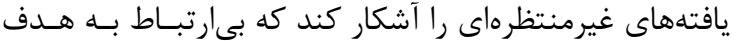

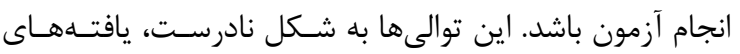

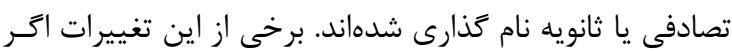

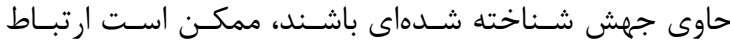

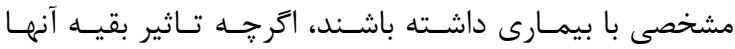
ناشناخته باقى بماند. اينكه كدام يافتهها بايد دردسترس بيدار بيمـار

$$
\text { قرار كيرد در دست بررسى است (TF). }
$$

آزمون هاى عرضه مستقيم به مصرف كننده (DTC)

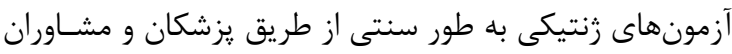

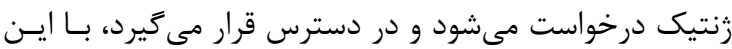

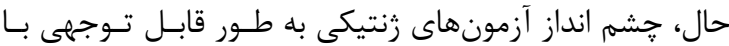

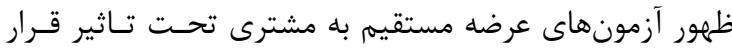

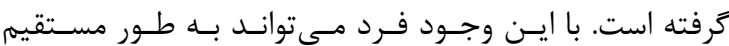
درخواست آزمون زنتيكى بدهد و اغلب نتايج آن بدون دخالـت

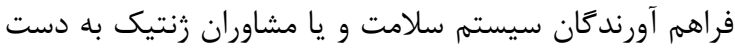

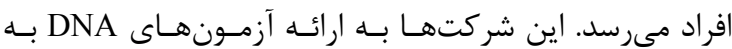

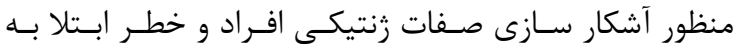

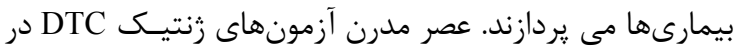

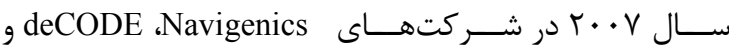

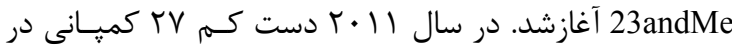
آمريكا آزمونهاى Direct To Consumer را عرضه مىكردنـد.

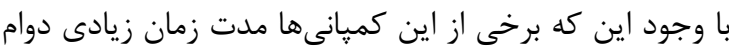

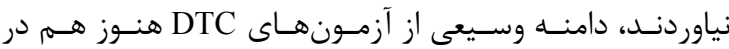
دسترس هستند. دسترسى به اسكن رنوم توسط DTC بسـيار

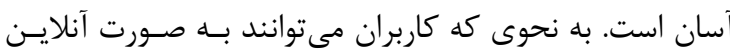

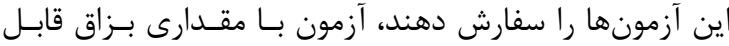

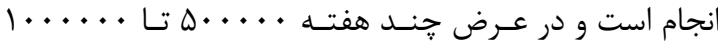

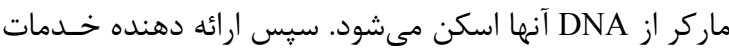
براساس تركيب ويزهاى از ماركرها به اندازه كيرى خطـر ابـتلا

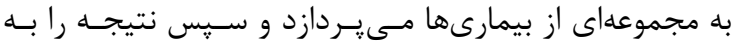

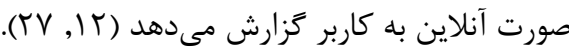
يكى از جنبههاى ظهور آزمونهـاى زنتيـك DTC اسـتفاده از

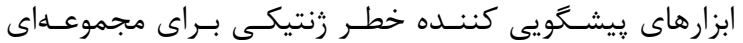

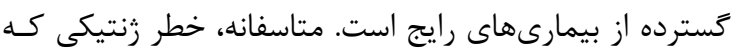
به وسيله DTC برآورد مىشود معمولا براى بيمارىهاى رايسج توانايى קِيش بينى كم تـا متوسـط دارد، كـه علـت آن ميـزان

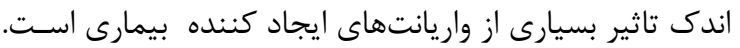

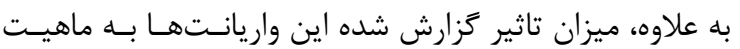

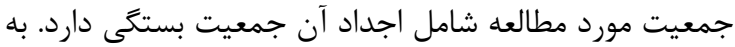

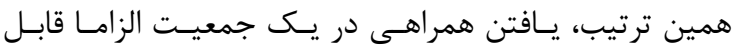

بيمارىهاى رايج و وييجيده مانند ديابت نـوع II ،يمـارىهـاى

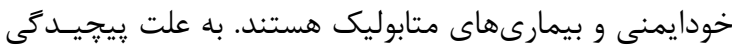
زنتيكى ارثى اين بيمارىها، تاثير زنتيكى ايجاد شده به وسيله

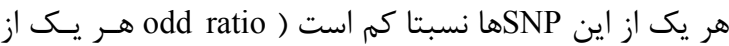
اين عاملهاى خطر كمتر از إس است) و در بين جمعيت استهايى

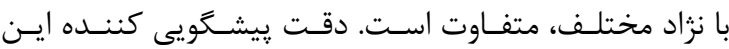

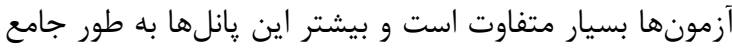

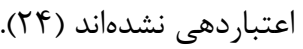

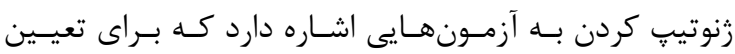

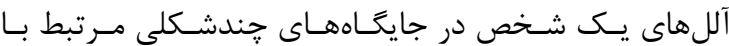

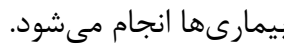

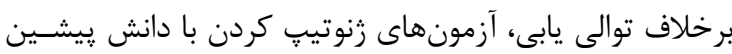
از وجود تنوعهاى زنتيكى خاص مانند SNP هاى رايج، طراحى إنى مىشود. انتشار صدها مطالعه كسترده زنومى (GWAS) هزاران واريانت رايج تغيير دهنده با تاثير خيلى اندك در خطر ابتلا به بيمارى ها را شناسايى كرده است كه در بيمارى رهـاى بيجيجيـده

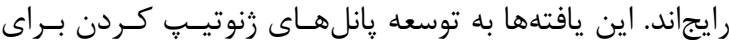

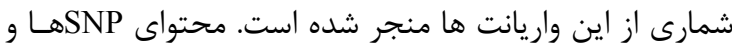

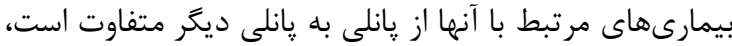
اخر جه هم يوشانىهايى بين واريانتهاى بسيار رايج وجود دارد.

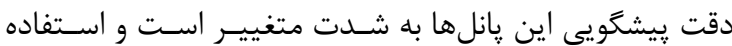
بالينى از اين آزمونها پايه كذارى نشده و هنوز ناشناخته باقى

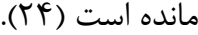

د) ت المالى يابى اتزوم يا كل زنوم

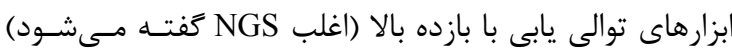

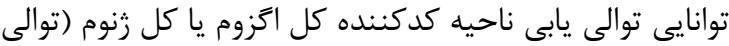
كدكننده يروتئين و عاملهاى تنظيم كننده) را دارد. اسـتفاده

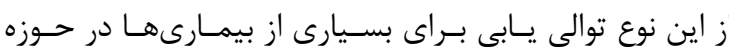
يزووهش باقى مانده است، به اين علت كه تفسير مقـدار بسـيار زيادى از دادههاى حاصل از اين آزمونها مشكل است. معمـولا

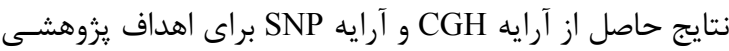

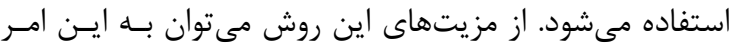
اشاره كرد كه اكر توالى يابى كل زنوم انجام شود توانايى فراهم آنمان

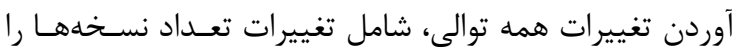

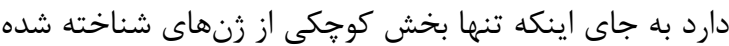

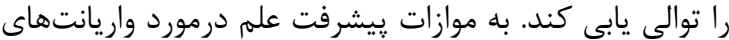

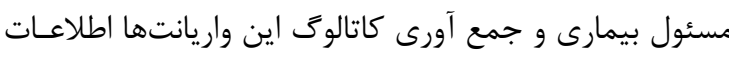

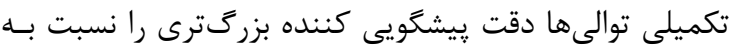

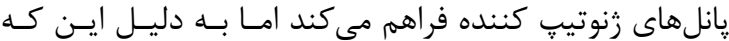

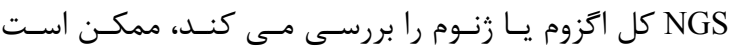


در زن و واريانتها متفاوت باشند كه اين امـر بــر روى تفسـير

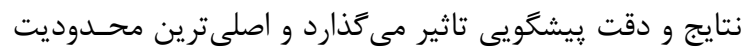

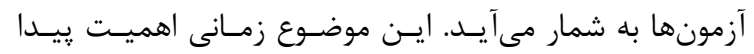

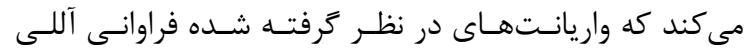

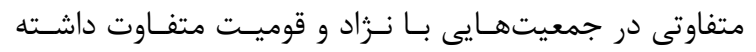

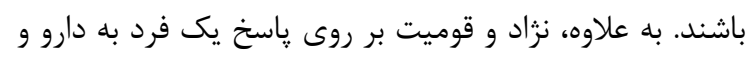
بروز اثرات جانبى يك دارو موثر است. وجود هترورنى در بـين

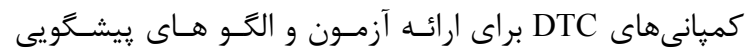
كننده براى تخمين خطر، اين يرسش را مطرح كـرد كـهـ جـهـ إنه

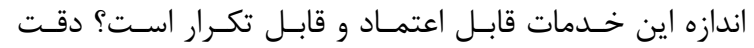
شناسايى جهشها يـا SNPهـاى مـرتبط بـا بيمـارى يكىى از

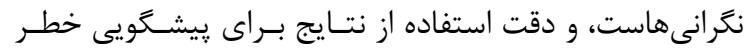
ابتلا يكى نكرانى جداگانه، برابرو حتى بزرگتر ايجاد كرده است

(Tt, (TY)

يك شركت DTC ممكن اسـت نتـايج مربوطـه را سـريعتــ از خدمات بهداشتى و درمانى با فهرسـتهـاى بلنــد مـدت ارائسه دهد، و نظر به اين كه نتايج مستقيم به دست مصـرف كنـــده

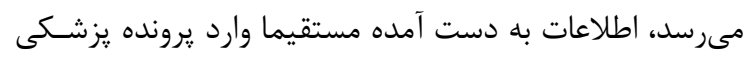

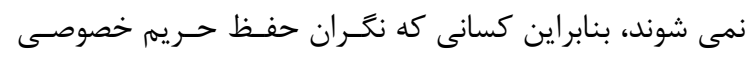

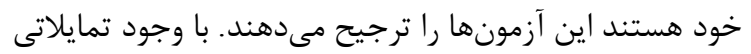

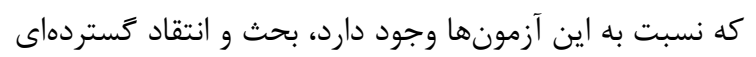

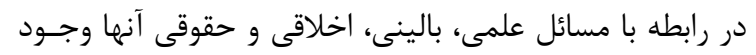
دارد. اعتبار بالينى و كاربرد آزمونهاى خاصى، به ويزه در موريط، مورد

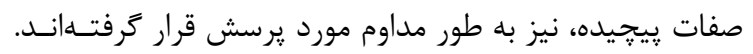

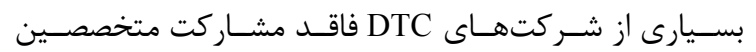
بهداشتى آموزش ديده و كسب رضايت افراد در زمينه انتخــاب

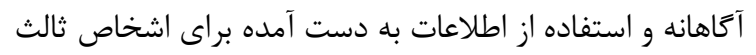

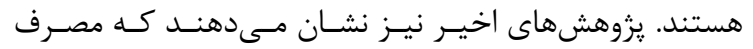

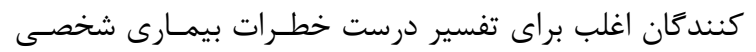
خود به كمك نياز دارند. اگر مصرف كنندكان با دريافت نتـايج

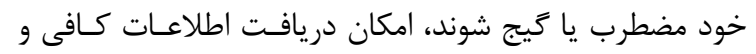
يشتيبانى از شركت DTC براى آنها وجود نــدارد، بنـابراين بـهـ

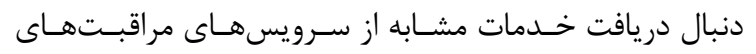

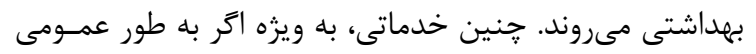

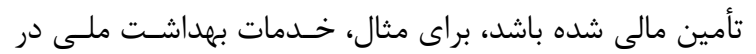

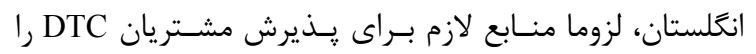

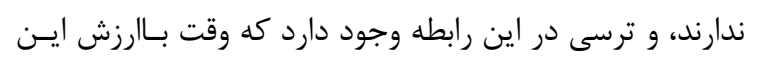

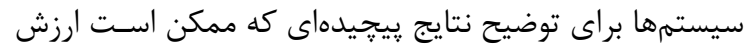
بالينى محدود داشته باشد و در نهايت هم منجــر بــه مـديريت

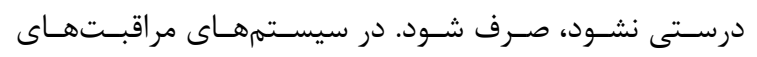

تعميم به جمعيت ديكر به نزاد يا قوميـت متفــاوت نيسـت. دو نكرانى اصلى كه در رابطه با آزمونهاى DTC وجــود دارد: آيـا

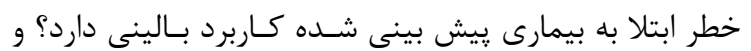

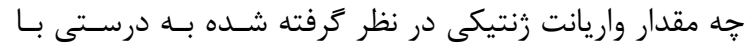

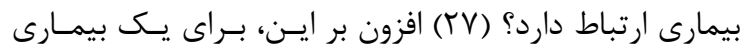

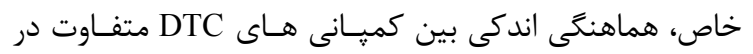

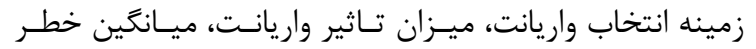
جمعيتى، الكوريتم مورد استفاده براى تخمين خطر وجود دارد

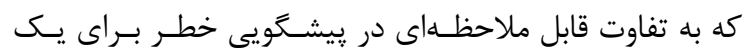
شخص در كميانىهاى مختلف منجر مىشود. به عنـوان مثــال

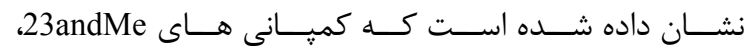
Navigenics و به جز براى بيمارىهاى تخريسب

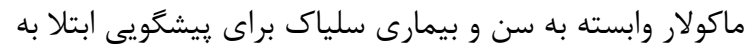

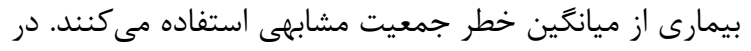

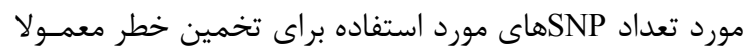

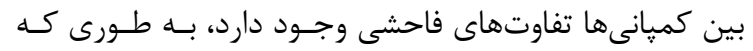

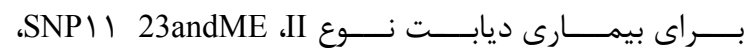

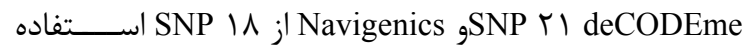

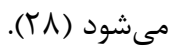

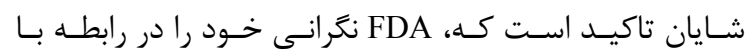
سواستفاده از اطلاعات زنتيكى ززارش شده به علـت مــديريت نادرست اعلام كرده است. به عنوان مثال، بيماران ممكن است تصميمات درمانى مانند برداشت يستان، شـيمى درمـانىهـاى ييشخيرانه يا دريافت مراقبت هاى ناصحيح در رابطه با زنوتئي

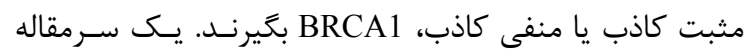
نويس بيشنهاد كرد كه ممكن است FDA اجـازه انجـام ايسن

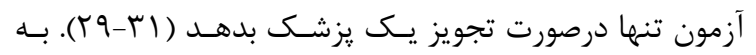

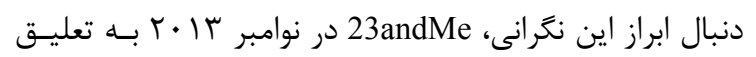

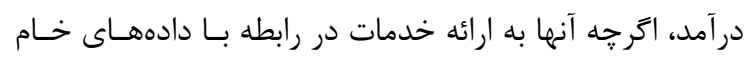

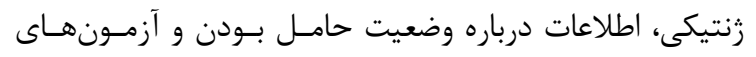

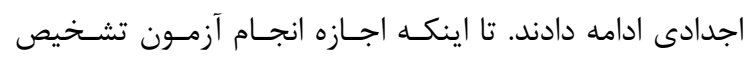

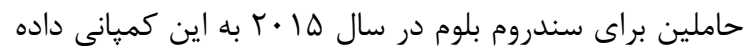

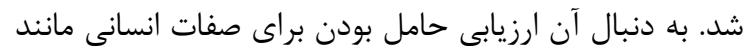

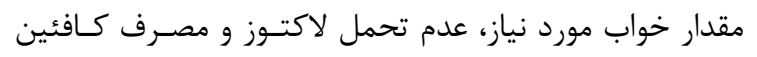

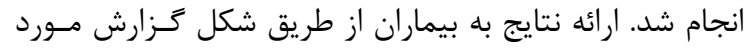

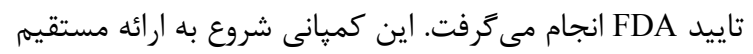

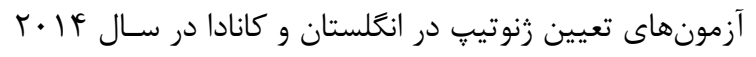

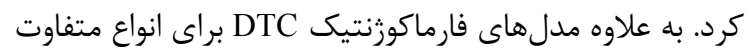
دارو-زن ها در دسترس است. مشابه با DTCهاى تخمين خطر

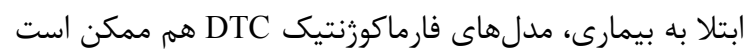




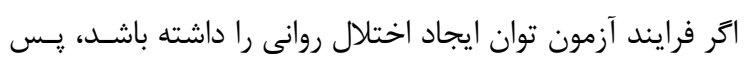

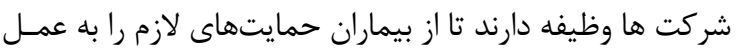

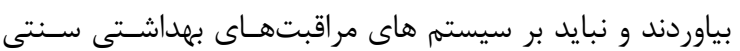
تكيه كنند تا اين حمايت را فراهم بياورد (سب).

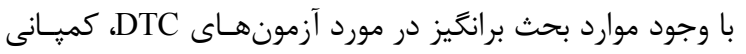

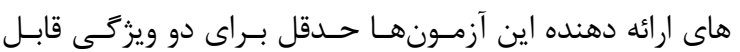

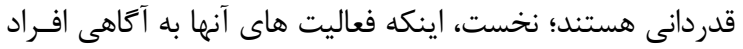
از وضعيت زنوم خود و ارتباط آن با پاسخهاى درمانى منجر شده

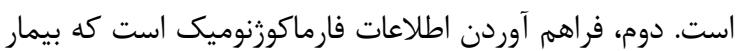

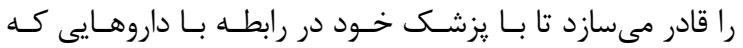

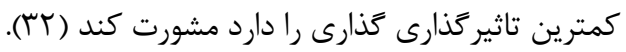

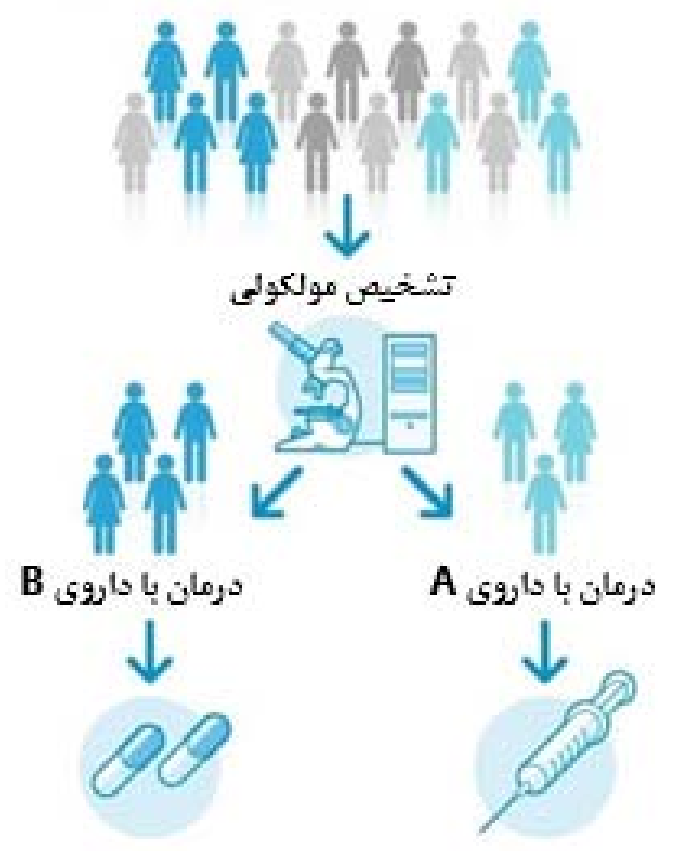

شكل r. نمايش سادهاى از فارماكوزنتيك.

\section{آزمونهاى فارماكوزنتيك بالينى و كاربرد آنها}

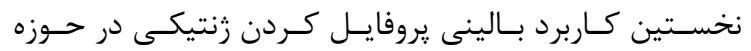

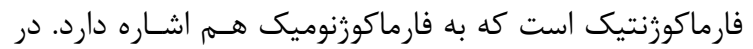

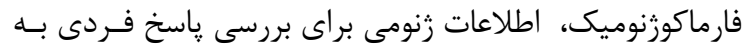

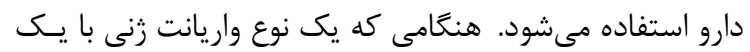

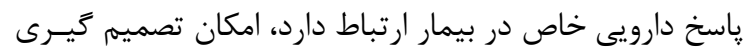

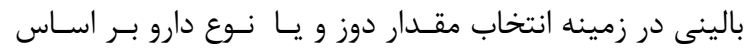

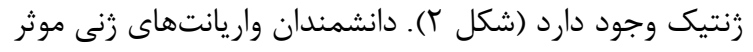

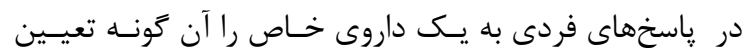
مى كنند كه واريانتهاى مر تبط با بيمارىها را تعيين مى كنيند:

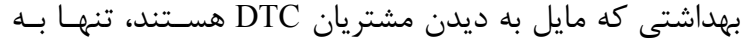

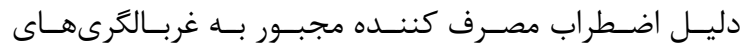
غيرضرورى هستند. همجنين شواهد محدودى وجود دارد كـهـ

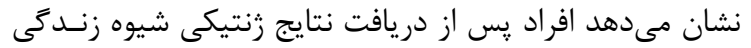

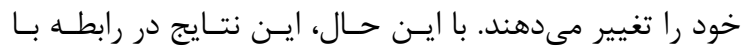

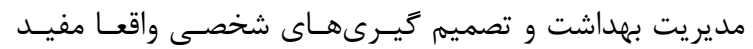

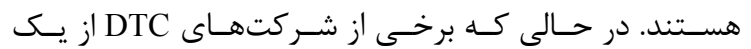

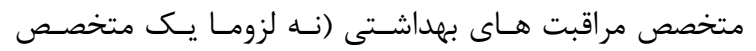

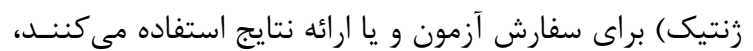

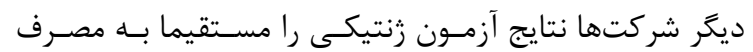

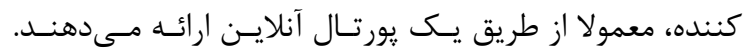

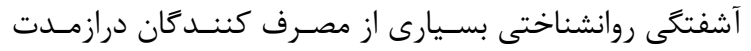

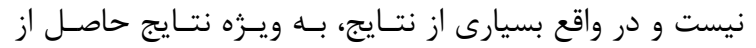

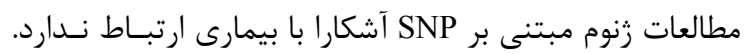

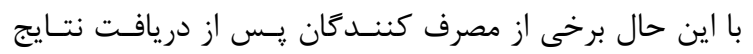

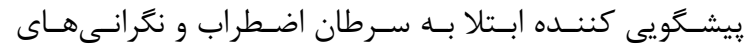

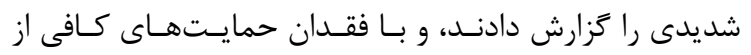

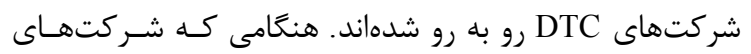

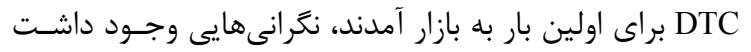

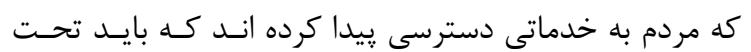

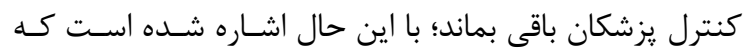

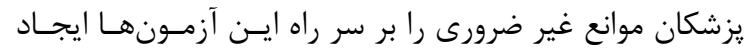

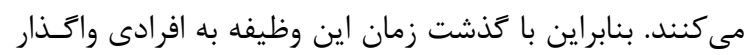

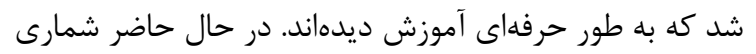

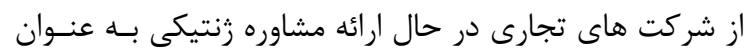

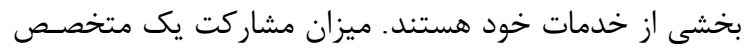

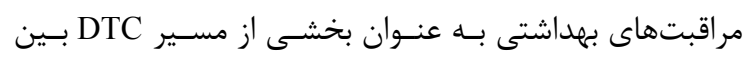

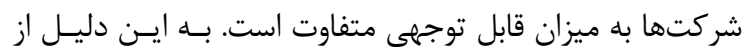

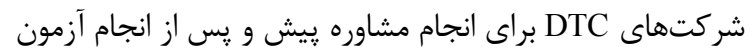

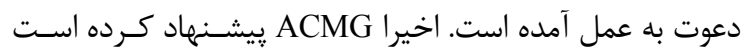

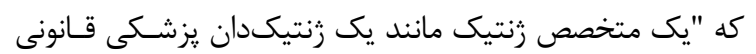

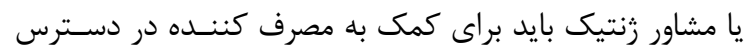

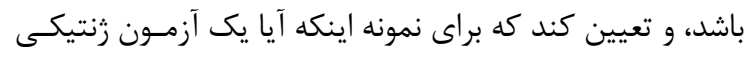

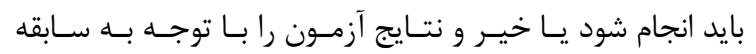

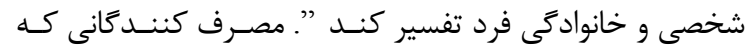

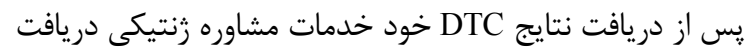

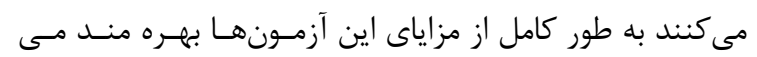

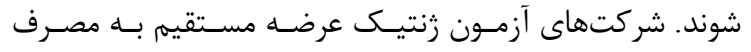

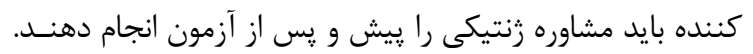
در حالى كه ما از مشاوره زنتيك اجبارى حمايت نمى كنـيمه، امـا 
باشد. به عنوان مثال، گَيرنـده آدرنرزيـك بتـا ه هـدف هـر دو

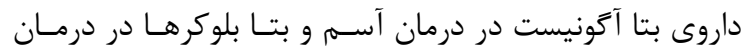

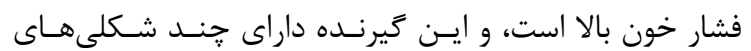
مرتبط با ياسخ به اين داروهاست (ه山).

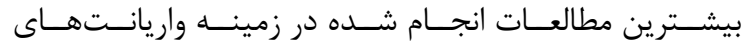
فارماكورنوميك بـر روى داروى سـيتوكروم P450 (متابوليسـم ميسم

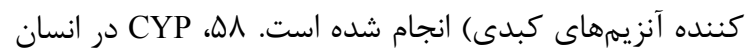
شناسايى شده است و SNPSPاى تغيير دهنـده فعاليـت بيشـتر

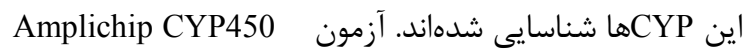
از نظر بالينى در آمريكا به شكل ميكروآرايه اليخونو كلئوتيدهاى

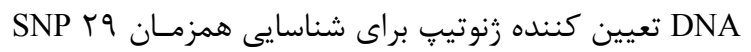
در زن هاى CYP2D6 و CYP2C19 در دسترس است (YY) اين واريانتها روى متابوليسم شـمار زيـادى از داروهــا تجـويز

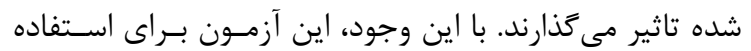

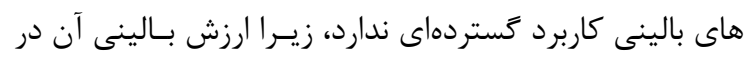

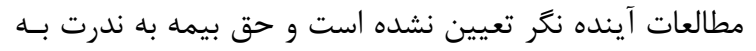

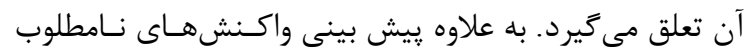

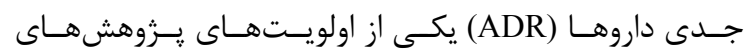
فارماكولوزيك است. براى مثال، آنزيم CYP2D6 يكى از آنزيم-

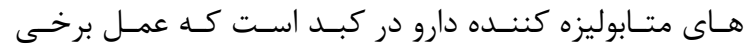

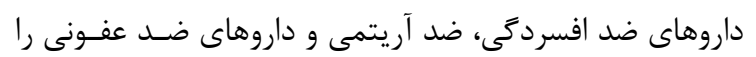

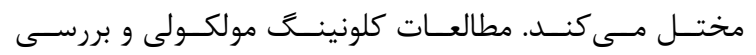

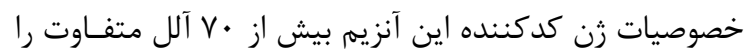

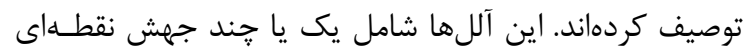

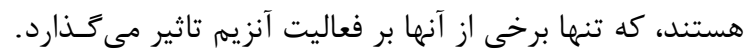

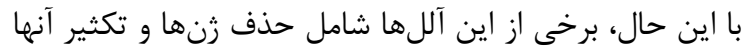

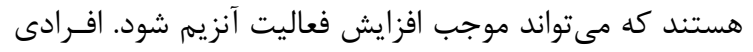

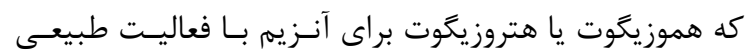

با شناسايى جايكاه هاى زنتيكى مرتبط با واكنش هاى شناخته

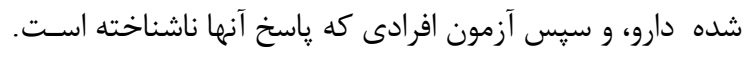

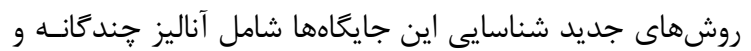
يروفايل كردن קند شكلى هاى نوكلئوتيـدى كـل زنـوم (SNP) است، اين روشها به منظور كشف و توسعه دارو مـورد اسـتفاده

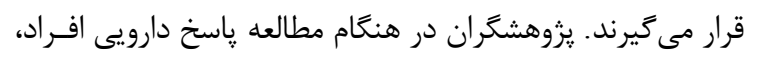

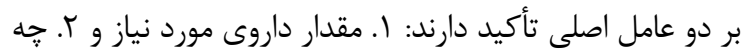

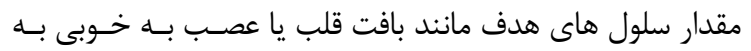

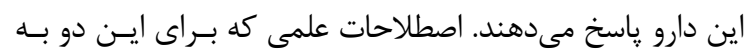
كار مىرود، فارماكوكينتيك و فارماكوديناميك است، و هــر دو از

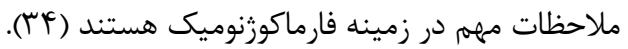

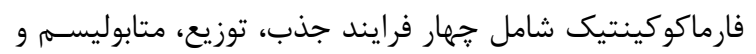
دفـع در ادرار اســت كــه اغلـب بـهـ عنــوان ADME شـــاخته مىشود. جذب معمولا به ورود دارو بـهـ جريسان خـون يـس از

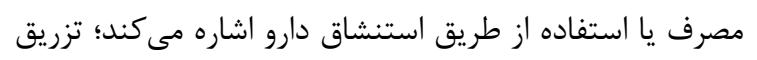
درون وريدى با واردكردن مستقيم دارو به جريـان خــون، ايـن

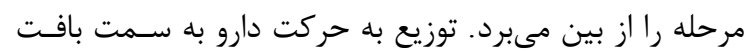

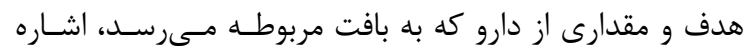

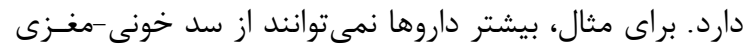

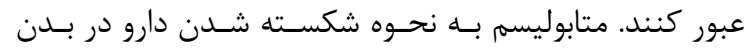

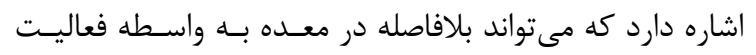

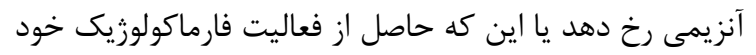

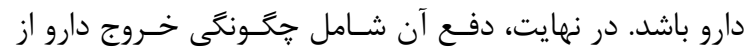
بدن از طريق ادرار، صفرا و در برخـى مـوارد استنشـاق اسـت.

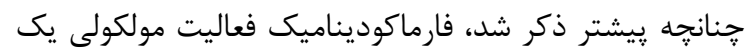
دارو بر روى هدف آن است، جه هدف آن سطح سلولى (بـراى

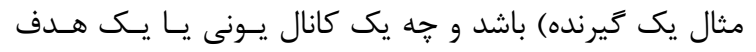

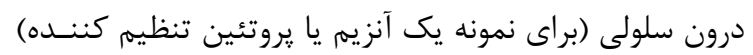

جدول r. داروهاى شخصى سازى شده مورد تاييد سازمان تحقيق و ارزيابى دارو

\begin{tabular}{|c|c|c|}
\hline بيوماركر تعيين كننده پاسخ درمانى & بيمارى & نام دارو \\
\hline BRCA & سرطان ييشرفته تخمدان & (olaparib) Lynparza \\
\hline 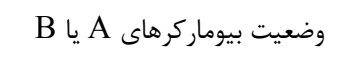 & موكويلى ساكاريدوز نوع IV (نشانكان موركيو) & (elosulfase alpha) Vimizim \\
\hline ALK L EGFR & آدنوكارسينوماى متصل به دستًَاه كَوارش & (ramucirumab) Cyrazma \\
\hline UGT1A1 & لنفوم محيطى T-Cell & (Belinostat) Beleodaq \\
\hline CYP2D6 & 1 كوجر نوع 1 & (eliglustat) Cerdelga \\
\hline زنوتايٍ ا عفونت ويروسى & ع ع ع منت من هياتيت C & (sofosbuvir, ledipasvir) Harvoni \\
\hline رنوتايب ا عفونت ويروسى & عفونت مزمن هياتيت C & $\begin{array}{r}\text { (ombitasvir, paritaprevir, Viekira Pak } \\
\text { ritonavir, dasabuvir) }\end{array}$ \\
\hline 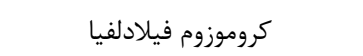 & لوكمى لنفوبلاستى حاد) & (blinatumomab) Blincyto \\
\hline
\end{tabular}


خاص تحت تأثير קجندين عامل است، به نظر مىرسد كه

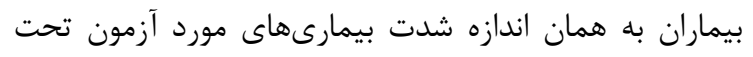

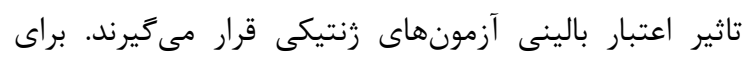

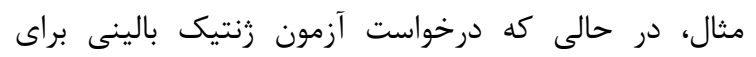

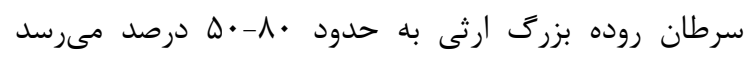

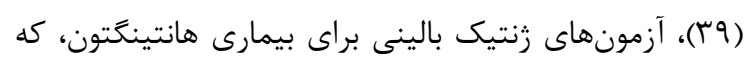

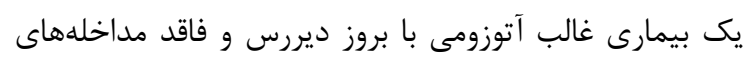

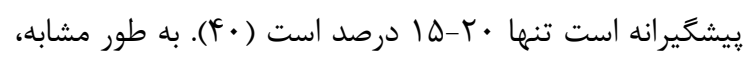

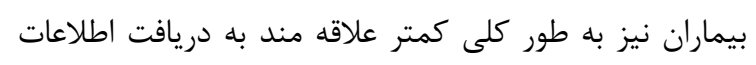

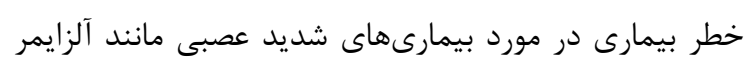

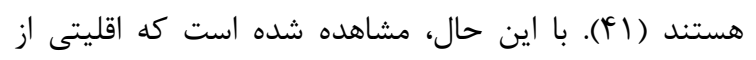

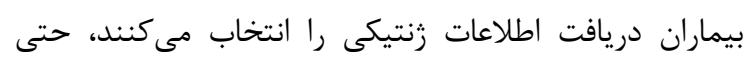

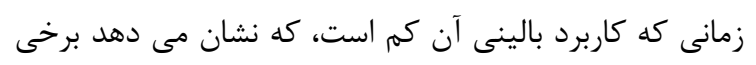

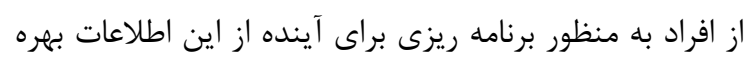

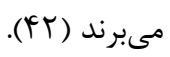

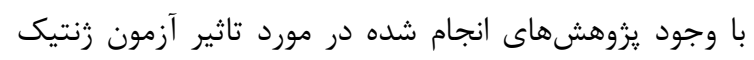

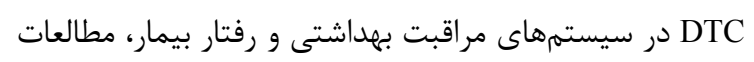

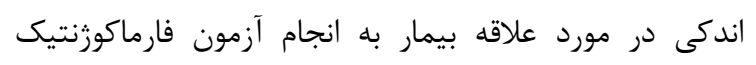

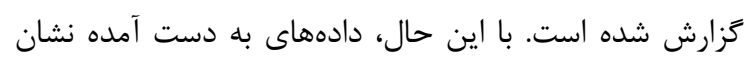

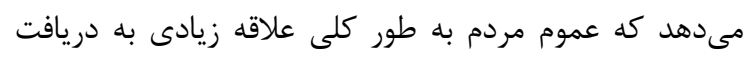

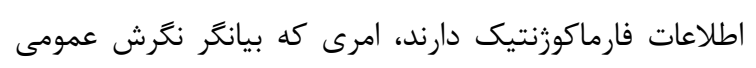

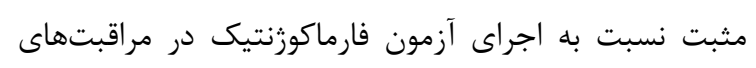

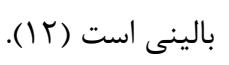

\section{ييامدهاى روانشناختى}

در عرصه زنتيك يزشكى، آسيب روانى ناشى از اطلاعات آزمون

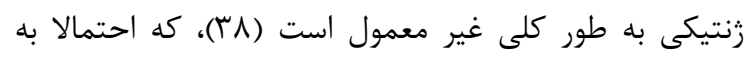

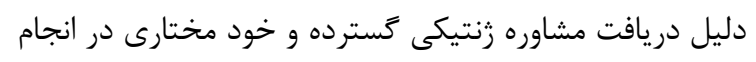
اين آزمون است، به نحوى كه هنكامى كه بيماران آنساس

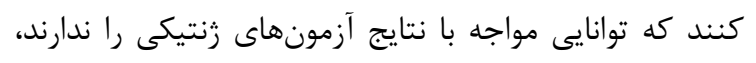
مىتوانند انتخاب كنند كه از نتايج آزمونها آكاه نشوند (بأئ).

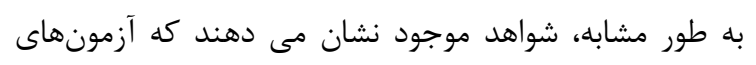

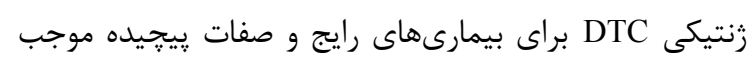

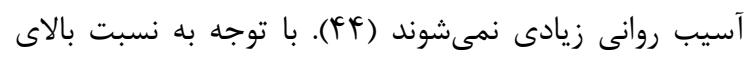

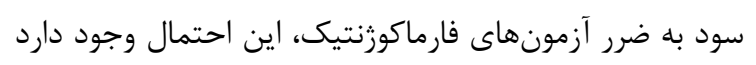

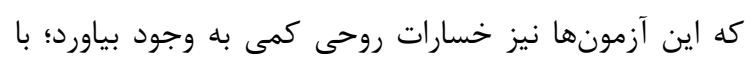

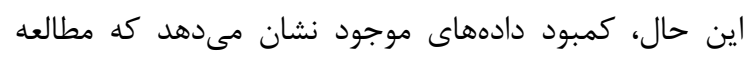

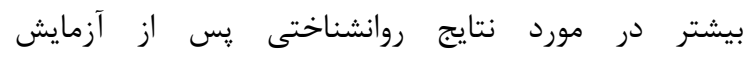

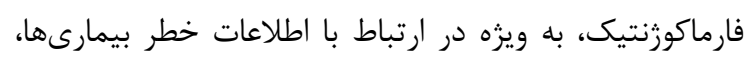

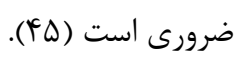

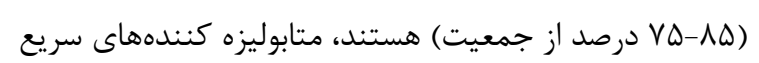

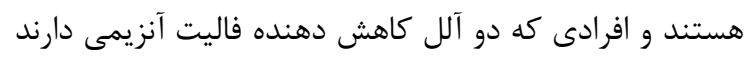

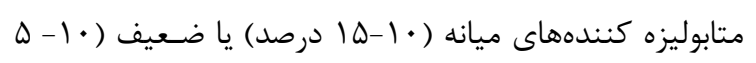

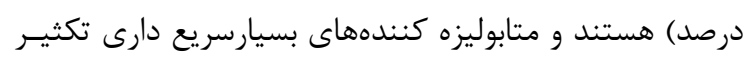

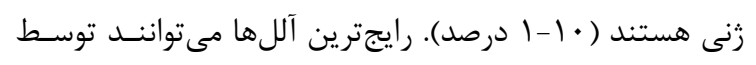

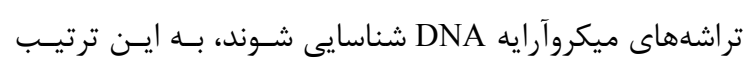

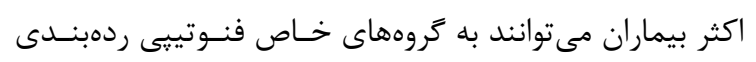

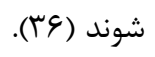

داروهاى توسعه يافته بر اساس بز شككى شخصى شده

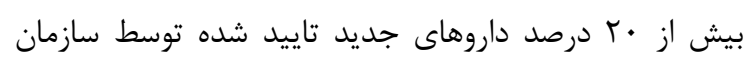

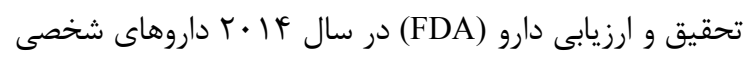

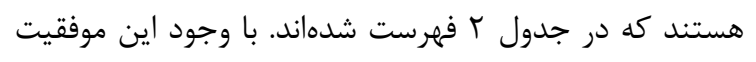

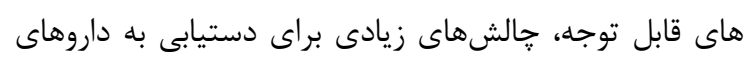

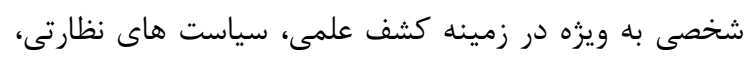

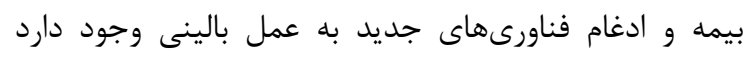

واكنش بيماران به نتايج آزمون هاى زنتيك شخصى شده

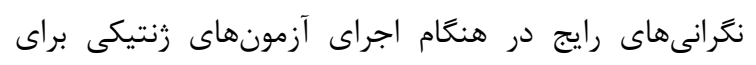
يزشكى شخصى شده، اغلب بر زيرساخت، تداركات و ديخر

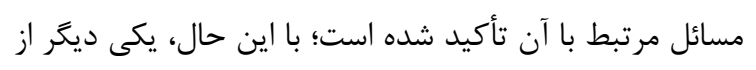

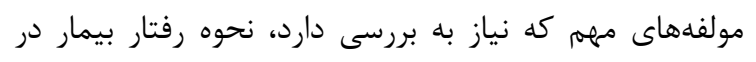

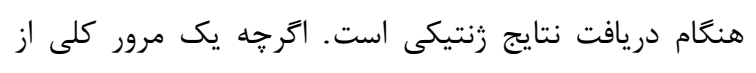

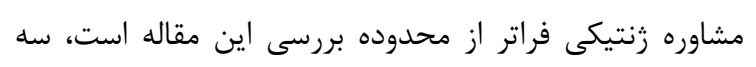

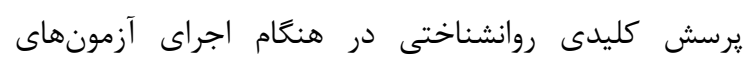
زنتيك يزشكى شخصى بايد در نظر ترفته شود:

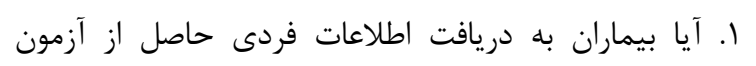

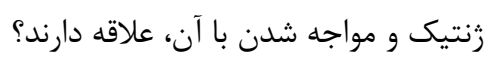

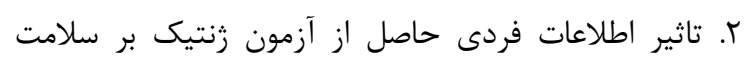

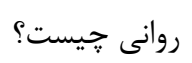
r. آيا اطلاعات فردى حاصل از آزمون زنتيك، انكَيزه بيماران

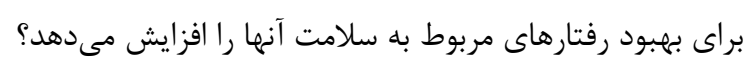

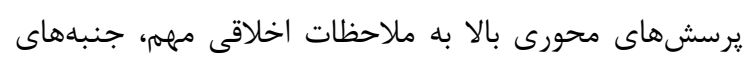

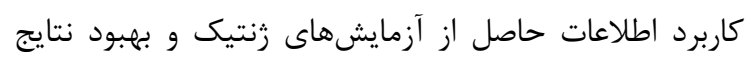

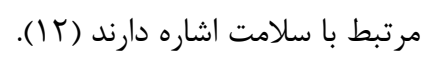
علاقه بيمار به دريافت نتايج زنتيكى شخصى

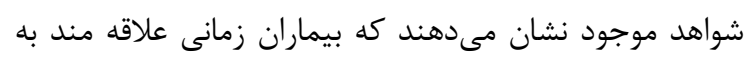

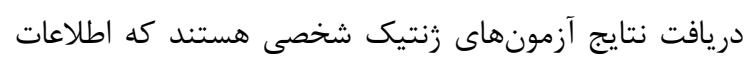

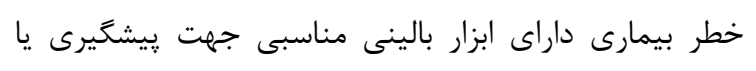

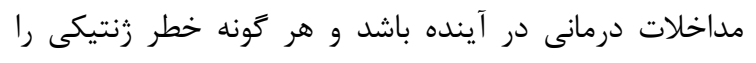

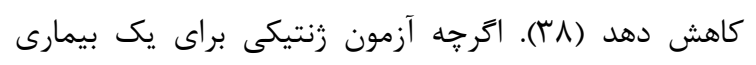


در زير ميكروسكوب، آنها شاهد كروموزومهايى با وجود

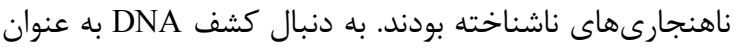
اساس مولكولى وراثت و تعيين ساختار آن، اين تفكر مورد باند

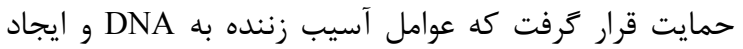

جهش مى تواند منجر به بروز سرطان كردد (• (ه).

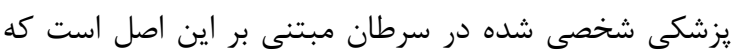

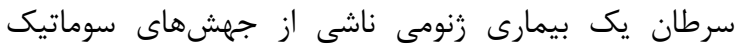

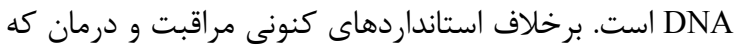

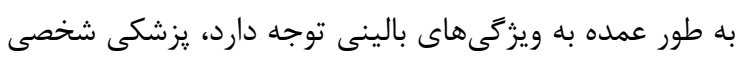
شده در سرطان شامل توسعه و تعيين درمان بر اساس تغييرات زنومى است كه ايجاد كننده تومور و حفظ كنينده تندي

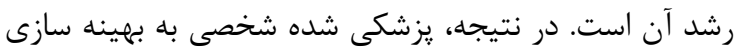

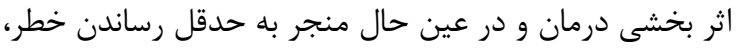

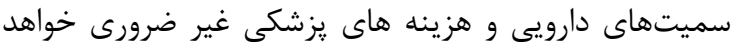

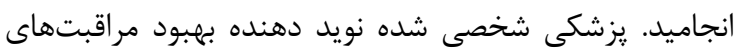

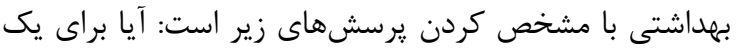

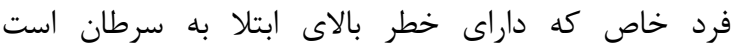

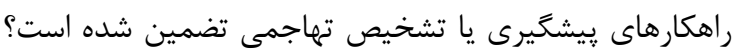
جه درمان ابتدايى براى بيمار مناسبتر خواهد بود؟ آيا يك ديك

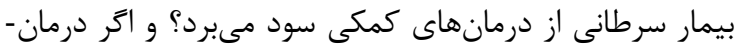

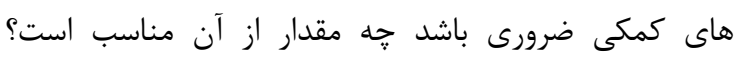

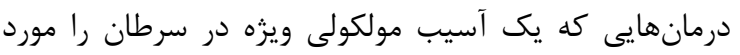
هدف قرار مىدهند، اساس درمان يزشكى شخصى شئ شده

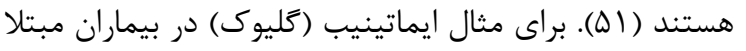
به لوكمى حاد ميلوئيد (CML) كه داراى كروموزوم فيلادلفيا (مانيا با ادغام زن BCR-ABL هستند بسيار موثر است. به نحوى كه

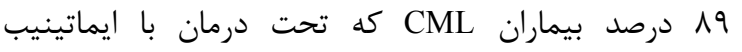

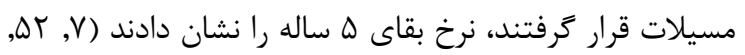

بيوماركرهاى مولكولى(DNA، RNA، يروتئين، متابوليك و ...)

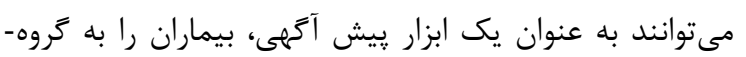

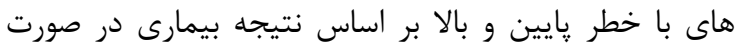

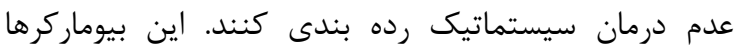

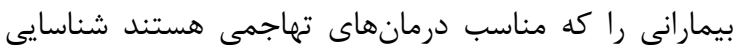
مى كنند؛ بنابراين بيماران با خطر اندك مى توانند از بار درمان-

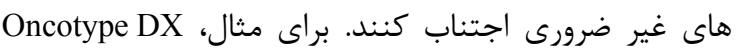

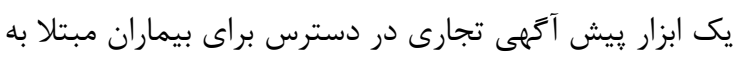

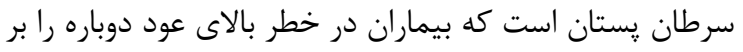

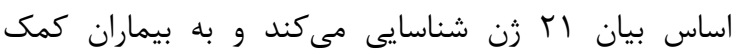

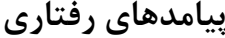

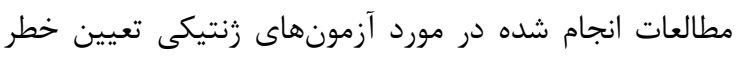

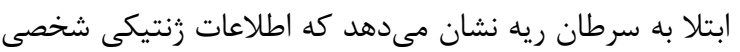
به طور مستقل تاثير قابل توجهى در ايجاد انخيزه براى تغيير

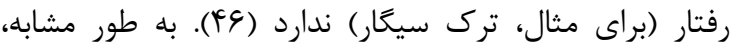

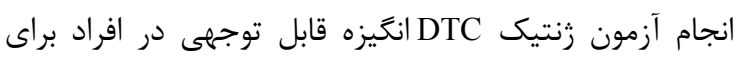

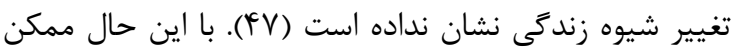

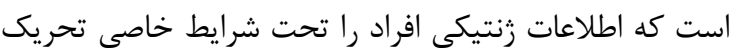

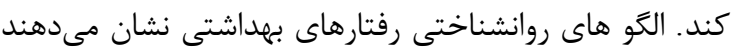

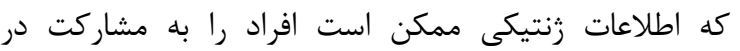

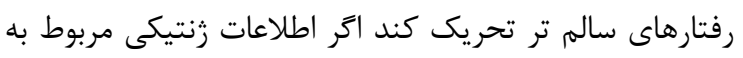

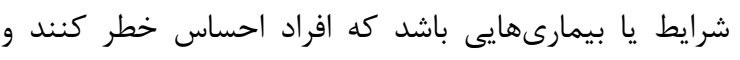

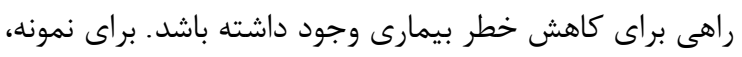

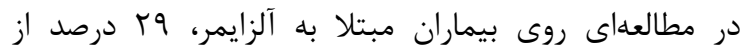

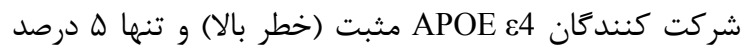

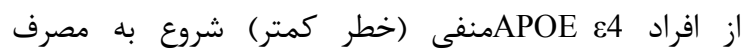
مكملهاى غذايى به منظور كاهش خطر بيمارى خود كردئ

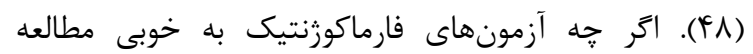

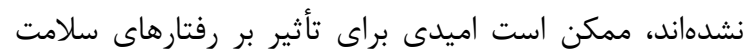
بيمار وجود داشته باشد. براى مثال، دادههاى به دست دست آمداي

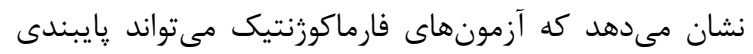

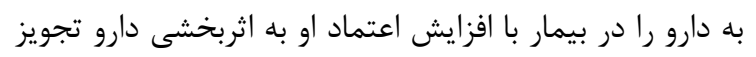

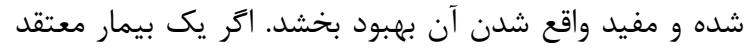

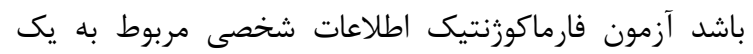

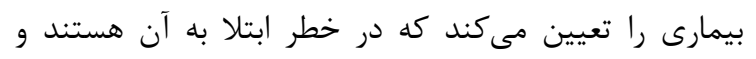

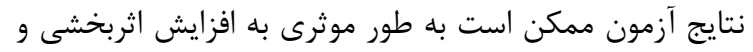

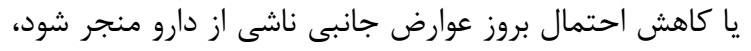

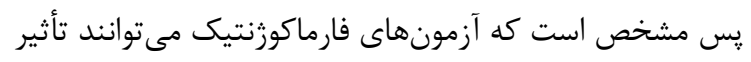

مثبتى بر קايبندى داروها داشته باشند (F) (F).

\section{يزشكى شخصى شده و سرطان}

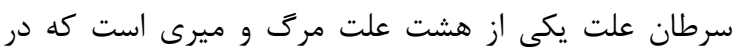

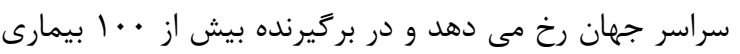

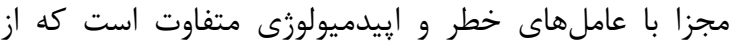

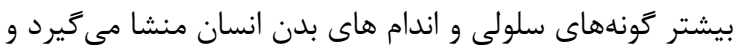

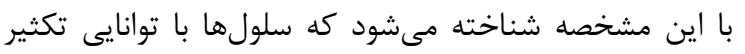

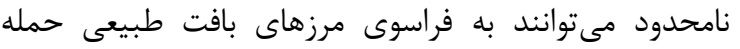

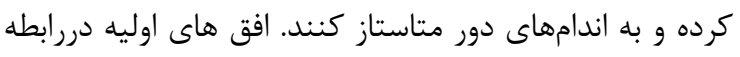

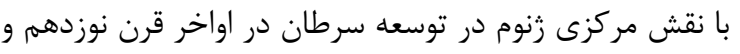

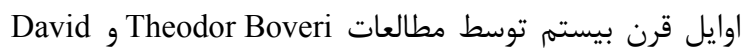
شكل كرفت. با بررسى سلولهاى در حال تقسيم Hansemann 


$$
\begin{aligned}
& \text { ابتلا براى بيمارىهاى رايج خطرناك بىترديد راههاى جديدى }
\end{aligned}
$$

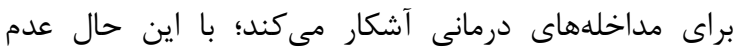

$$
\begin{aligned}
& \text { تاثيرقطى بيشتر اين واريانتهاى شناخته شده به به اندازي }
\end{aligned}
$$

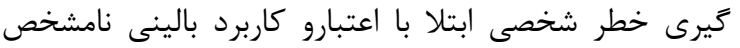

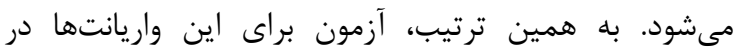

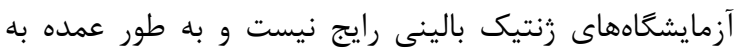

$$
\begin{aligned}
& \text { شركتهاى آزمايشًاهى DTC محدود شده است. در حال حال } \\
& \text { حاضر مطالعات توالى يابى رنوم احتمالا واريانتهاى نادرى كه }
\end{aligned}
$$

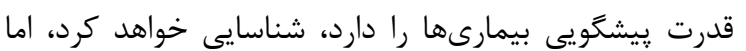

$$
\begin{aligned}
& \text { روشن است كه توسعه الكوريتمهاى بِيش بينى خطر ضرورى }
\end{aligned}
$$

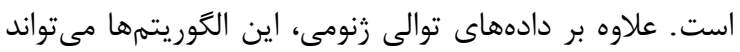

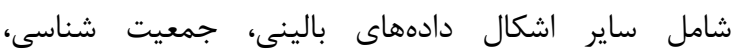

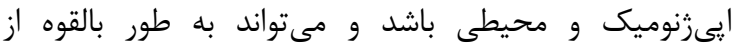

$$
\begin{aligned}
& \text { روشهاى يِيشرفتهتر الكو سازى مبتنى بر شبكه استفاده كند }
\end{aligned}
$$

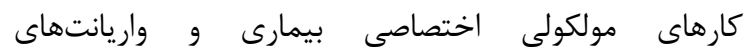

$$
\begin{aligned}
& \text { فارماكوزنوميك بيمار مىشود (DV). }
\end{aligned}
$$

\section{REFERENCES}

1. Sugeir S, Naylor S. critical Care and Personalized or Precision Medicine: Who needs whom? J Crit Care 2018;43:401-5.

2. Schork NJ. Personalized medicine: time for one-person trials. Nature 2015;520:609-11.

3. Goetz LH, Schork NJ. Personalized medicine: motivation, challenges, and progress. Fertil Steril 2018;109:952-63.

4. Wong SHY. Pharmacogenomics and personalized medicine, Handbook of Drug Monitoring Methods 2008:211-23.

5. Khoury MJ. The shift from personalized medicine to precision medicine and precision public health: Words matter. CDC Blogs, 2016.

6. Hill L. What is the difference between precision medicine and personalized medicine? What about pharmacogenomics? 2018.

7. Noori Daloii MR. Medical molecular genetics in the third millennium. Tehran: Samer Publication, 2012. [In Persian]

8. Noori-Daloii MR. Emery's elements of medical genetics. 8th ed. Tehran: Jame-e-negar and Salemi Publication, 2012. [In Persian]

9. Hudson T. Genome variation and personalized cancer medicine. J Intern Med 2013;274:440-50.

10. Le Tourneau C. Molecularly targeted therapy based on tumour molecular profiling versus conventional therapy for advanced cancer (SHIVA): a multicentre, open-label, proof-of-concept, randomised, controlled phase 2 trial. The lancet oncol 2015;16:1324-34.

11. Li YY, Jones SJ. Drug repositioning for personalized medicine. Genome Med 2012;4:27.

12. Abul-Husn NS, Owusu Obeng A, Sanderson SC, Gottesman O, Scott SA. Implementation and utilization of genetic testing in personalized medicine. Pharmacogenomics Pers Med 2014;7:227-40. 
13. Vogenberg FR, Barash CI, Pursel M. Personalized medicine: part 1: evolution and development into theranostics. P T 2010;35:560-76.

14. Emmert-Streib F. Personalized medicine: Has it started yet? A reconstruction of the early history. Front Genet 2013;3:313.

15. Lu YF, Goldstein DB, Angrist M, Cavalleri G. Personalized medicine and human genetic diversity. Cold Spring Harb Perspect Med 2014;4:a008581.

16. Hunt S. Pharmacogenetics, personalized medicine, and race. Nature Educat 2008;1:12.

17. Ortega VE, Meyers DA. Pharmacogenetics: implications of race and ethnicity on defining genetic profiles for personalized medicine. J Allergy Clin Immunol 2014;133:16-26.

18. Zanger UM, Raimundo S, Eichelbaum M. Cytochrome P450 2D6: overview and update on pharmacology, genetics, biochemistry. Naunyn-Schmiedeberg's Arch Pharmacol 2004;369:23-37.

19. Ashley-Koch A, Yang Q, Olney RS. Sickle hemoglobin (Hb S) allele and sickle cell disease: a HuGE review. Am J Epidemiol 2000;151:839-45.

20. Aidoo M, Terlouw DJ, Kolczak MS, McElroy PD, ter Kuile FO, Kariuki S, et al. Protective effects of the sickle cell gene against malaria morbidity and mortality. Lancet 2002;359:1311-2.

21. Slatkin MA. Population-genetic test of founder effects and implications for Ashkenazi Jewish diseases. Am J Hum Genet 2004;75:282-93.

22. Ostrer H. Skorecki K. The population genetics of the Jewish people. Hum Genet 2013;132:119-27.

23. Ge D, Fellay J, Thompson AJ, Simon JS, Shianna KV, Urban TJ, et al. Genetic variation in IL28B predicts hepatitis C treatment-induced viral clearance. Nature 2009;461:399-401.

24. Raby BA. Personalized medicine. UpToDate:2017.

25. Noori-Daloii MR, Eshaghkhani Y. lncRNAs: significance and function mechanisms. Med Sci J Islamic Azad Univ Tehran Med Branch 2015:79-94.

26. Noori-Daloii MR, Fazilaty H, Tabrizi M. Cancer metastasis, genetic and microenvironmental factors of distant tissue: a review article. Tehran Univ Med Sci 2013:70.

27. Ng PC, Murray SS, Levy S, Venter JC. An agenda for personalized medicine. Nature 2009;461:724-6.

28. Kalf RR, Mihaescu R, Kundu S, de Knijff P, Green RC, Janssens AC.Variations in predicted risks in personal genome testing for common complex diseases. Genet Med 2014;16:85-91.

29. Imai K, Kricka LJ, Fortina P. Concordance study of 3 direct-to-consumer genetic-testing services. Clin Chem 2011;57:518-21.

30. Noori-Daloii MR, Nikpour B. Gene therapy in cancer and its development. Journal of Razi 1999;10:9-28. [In Persian]

31. Noori-Daloii MR, Tabarestani S. Molecular Genetics and gene therapy in breast cancer. The Journal of Faculty of Medicine. J Sabzevar Univ Med Sci 2010;17:74-87. [In Persian]

32. Chua EW, Kennedy MA. Current state and future prospects of direct-to-consumer pharmacogenetics. Front Pharmacol 2012;3:152.

33.Middleton A, Mendes A, Benjamin CM, Howard HC. Direct-to-consumer genetic testing: where and how does genetic counseling fit? Per Med 2017;14:249-57.

34. Adams JU. Pharmacogenomics and personalized medicine. Nature Educat 2008;1:194.

35. Goldstein DB, Tate SK, Sisodiya SM. Pharmacogenetics goes genomi. Nature Rev Genet 2003;4:937.

36. Ingelman-Sundberg M, Oscarson M, McLellan RA. Polymorphic human cytochrome P450 enzymes: an opportunity for individualized drug treatment. Trends Pharmacol Sci 1999;20:342-9.

37. Analysis P. More Than 20 Percent of FDA's 2014 Novel New Drug Approvals are Personalized Medicines. 2015.

38. Lerman C, Croyle RT, Tercyak KP, Hamann H. Genetic testing: psychological aspects and implications. J Consult Clin Psychol 2002;70:784-97.

39. Ward RL, Hicks S, Hawkins NJ. Population-based molecular screening for Lynch syndrome: implications for personalized medicine. J Clin Oncol 2013;31:2554-62. 
40. Morrison P, Harding Lester S, Bradley A. Uptake of Huntington disease predictive testing in a complete population. Clin Genet 2011;80:281-6.

41. Roberts JS, Barber M, Brown TM, Cupples LA, Farrer LA, LaRusse SA, et al. Who seeks genetic susceptibility testing for Alzheimer's disease? Findings from a multisite, randomized clinical trial. Genet Med 2004;6:197-203.

42. Foster MW, Mulvihill JJ, Sharp RR. Evaluating the utility of personal genomic information. Genet Med 2009;11:570-4.

43. Sanderson SC, Wardle J. Associations between anticipated reactions to genetic test results and interest in genetic testing: will self-selection reduce the potential for harm? Genet Test 2008;12:59-66.

44. Bloss CS, Schork NJ, Topol EJ. Effect of direct-to-consumer genomewide profiling to assess disease risk. N Engl J Med 2011;364:524-34.

45. Haga SB, Tindall G, O'Daniel JM. Public perspectives about pharmacogenetic testing and managing ancillary findings. Genet Test Mol Biomarkers 2012;16:193-7.

46. Sanderson SC, Humphries SE, Hubbart C, Hughes E, Jarvis MJ, Wardle J. Psychological and behavioural impact of genetic testing smokers for lung cancer risk: a phase II exploratory trial. J Health Psychol 2008;13:481-94.

47. Roberts JS, Ostergren J. Direct-to-consumer genetic testing and personal genomics services: a review of recent empirical studies. Curr Genet Med Rep 2013;1:182-200.

48. Vernarelli JA, Roberts JS, Hiraki S, Chen CA, Cupples LA, Green RC. Effect of Alzheimer disease genetic risk disclosure on dietary supplement use. Am J Clin Nutr 2010;91:1402-7.

49. Haga SB, LaPointe NMA. The potential impact of pharmacogenetic testing on medication adherence. Pharmacogenomics J 2013;13:481-83.

50. Stratton MR, Campbell PJ, Futreal PA. The cancer genome. Nature 2009;458:719.

51. Garrett M, Dancikand DT. Bladder Cancer. 1ed. Mica Haley, 2018:724.

52. Druker BJ, Guilhot F, Brien SG, Gathmann I, Kantar jian H, Silver RT, et al. Five-year follow-up of patients receiving imatinib for chronic myeloid leukemia. N Engl J Med 2006;355:2408-17.

53. Noori-Daloii MR. Shahriar H. Telomerase and its inhibition in cancer. Tehran Uni Med J 2009;67:599-607. [In Persian].

54. Allison M. Is personalized medicine finally arriving? Nature Biotechnol 2008;26:509.

55. Takata R, Katagiri T, Kanehira M, Tsunoda T, Shuin T, Miki T, et al. Predicting response to methotrexate, vinblastine, doxorubicin, and cisplatin neoadjuvant chemotherapy for bladder cancers through genome-wide gene expression profiling. Clin Cancer Res 2005;11:2625-36.

56. Hayes DF, Markus HS, Leslie RD, Topol EJ. Personalized medicine: risk prediction, targeted therapies and mobile health technology. BMC Med 2014;12:37.

57. Mirnezami R, Nicholson J, Darzi A. Preparing for precision medicine. N Engl J Med 2012;366:489-91. 